\title{
Assessing the Future of Renewable and Smart Grid Technologies in Regional Energy Systems ${ }^{a}$
}

\author{
F. Babonneau ${ }^{b}$, A. Haurie ${ }^{c}$, G. J. Tarel ${ }^{d}$ and J. Théniée
}

JEL-Classification: Q41,Q42

Keywords: smart-grids, renewable energy sources, Switzerland, Geneva

\section{Introduction}

The European commitment to curb greenhouse gas (GHG) emissions and the phasing out of nuclear technology, in 2022 for Germany and 2034 for Switzerland, pose in the long term an important challenge to the electricity production and distribution system. Renewable energy sources, in particular wind and solar, will be tapped. Their intermittent production will have to be associated with temporary storage of electricity to facilitate the supply-demand equilibrium. Electric cars, if they penetrate strongly the market, will provide a storage facility, provided a smart grid development takes also place to permit a two-way communication between the electricity distributor and the car battery manager (АснA, Green, and Shah, 2010a; Galus and Andersson, 2008). One thus envisions a good complementarity between wind or solar electricity production and electric cars. Smart grid technologies may also induce a new form of coupling between the gas and the electricity grids (Acha, Green, and Shah, 2010b; Streckiene et al., 2009). The availability of small combined heat power (CHP) production units, with a capacity to store the heat energy for a deferred usage can foster the efficient use of natural gas for both residential heat and electricity generation

a This research has been supported by the GICC programme of the French Ministry MEDDEM, by the EUFP7-ERMITAGE research project, by the project RITES, financed by the Federal Office for Energy, Bern, Switzerland and by the Swiss-NSF-NCCR climate grant.

b ORDECSYS, Switzerland and Economics and Environmental Management Laboratory Swiss Federal Institute of Technology at Lausanne (EPFL), Switzerland.

c ORDECSYS, 4 Place de l'Etrier Chêne Bougeries, 1224 Switzerland. www.ordecsys.com.

d Economics and Environmental Management Laboratory - Swiss Federal Institute of Technology at Lausanne (EPFL), Switzerland.

e ORDECSYS, Switzerland. 
(Galus and Andersson, 2008; Marnay et al., 2008). The electricity production system will evolve toward more decentralization, with two-way communication channels permitting the coordination and optimization of the actions of myriad of agents involved in local consumption and production. This intelligent distribution system will also improve the system services like, e.g., peak-load or demand management (SHIN-ICHI, 2010).

The assessment of the future role of these renewable technologies in association with smart grid technologies can be made at a regional level, corresponding to the size of a local distribution grid. In Switzerland this corresponds to a cantonal or sub-cantonal level. In this paper we propose to represent smart grid technologies as well as intermittent electricity production into the energy-technology-environment model ETEM that is adapted for modeling energy systems at a regional level. The resulting model is applied to a case study, roughly calibrated on the Geneva cantonal data, to assess the future of renewable and smart grid technologies. To take into account some of the uncertainties on smart grids development, we complement our study with stochastic considerations on availability of green electricity imports (contingent, e.g., to the development of DESERTEC) and electric car technologies.

The paper is organized as follows: in Section 2 we present the general structure of ETEM; in Section 3 we detail the representation of renewable and smart grid technologies that are included in the technology choices of the model; in Section 4 we show the calibration of the model to the general situation of the canton of Geneva and we compare the energy system evolutions in three contrasted scenarios; in Section 5 we introduce long term uncertainty on the availability of "green electricity" imports at peak load time-slices and we observe the option value of the smart grid technologies; finally, in Section 6 we conclude by showing the necessary model developments to represent all the possible smart grid developments in the Geneva area and other regions in Switzerland. 


\section{ETEM}

\subsection{A Member of the MARKAL-TIMES Family of Models}

ETEM, for Energy-Technology-Environment Model $^{1}$, is a regional bottom-up model that has been designed for modeling energy systems at a regional level. ETEM is a bottom-up model that gives a representation of the energy and technology choices that could best deliver the needed energy services in a given region. The ETEM model rationale is to supply energy services at minimum global cost, over a planning horizon, typically of 45-50 years, permitting one to envision major changes in the technology portfolio. The total discounted cost, which is the objective function to be minimized, includes investment, operating cost and energy imports and exports. A salvage value takes into account the end-of-planning horizon valuation of the remaining technology capacities. The regional scope of ETEM makes it particularly well-suited to model and analyze renewable and smart grid technologies, which are necessarily connected to a regional distribution grid.

ETEM belongs to the family of MARKAL and TIMES models (BERGER et al.,1990; Loulou, Kanudia, and Lavigne, 1996). It is implemented in a versatile modeling language (GNU MathProg Language (GMPL), a free subset of AMPL (Fourer, Gay, and Kernighan, 1993)). The model has been developed on the basis of the Geneva case study, the complete code of this instance of the model is available on the internet ${ }^{2}$. MARKAL-like models for urban regions have been developed in Sweden (Sundberg, Gipperth, and Wene, 1994; Wene and RydÉN, 1988) for the city of Götteborg, in the US (HiLl, 1996) for the city of New York, and in Switzerland where a model has been developed to analyze the energy/environment policies in the canton of Geneva (FraGnière, 1995). Generally, the environmental problems taken into account have been mostly the emissions of atmospheric pollutants like $\mathrm{NO}_{2}, \mathrm{SO}_{2}$ and the emission of greenhouse gases (GHG), in particular $\mathrm{CO}_{2}$. A coupling of the MARKAL-LITE energy model (an early version of ETEM) and of an air-quality simulation model has been realized (CARLSON et al., 2004), and an analysis of the possible penetration of fuel cell cars in the energy system has been proposed (CARATTI et al., 2003); in this application the idle hydrogen fuel cell cars were used as producers of electricity at time of peak load, in a GHG emissions constrained scenario

1 For more information, see the reference manual (Drouet and Thénié, 2009) available on the web site www.ordecsys.com.

2 Please visit the web site www.ordecsys.com. 
for an energy system corresponding to the Geneva canton. A version of ETEM for Luxembourg has been developed and a coupling with an air pollution model has been realized (ZACHARY et al., 2011). Another open-source energy model, OSeMOSYS, similar to MARKAL and also programmed in GMPL has been recently announced by a group of prominent energy modelers (see Howells et al., 2011); the originality in this model is essentially the possibility to run it with free access open-source software, thus reducing the upfront cost of a modeling exercise. The introduction of the open-source model OSeMOSYS confirms the value of the options taken when developing ETEM.

An ETEM model has the following attractive features:

- flexible representation of an energy system, exploiting geographical data;

- fast techno-economic database building through a new web based interface;

- linkage ability with macro-economic or environmental simulation models;

- modularity and capacity to accept easily new features, like new equations to describe constraints at a local level, transmission and grid related constraints, nonlinear optimization, stochastic optimization, etc.

\subsection{The Reference Energy System}

ETEM is driven by projections of useful (energy services) demands, for different economic sectors, over a time horizon ranging between 25 and 100 years. These projections are determined by a set of drivers concerning, e.g., the demographic or GDP growth.

The model represents the investment in existing and new technologies and the associated commodity flows, including energy flows and pollutant emissions, necessary to satisfy the demands at a minimum total discounted system cost, i.e., a cost including the investment, maintenance and operation costs, discounted over the whole planning horizon at fixed rate of $3 \%$. The Reference energy system (RES) summarizes this ensemble of technologies regrouped in different categories. Conversion technologies produce electricity and low temperature heat, two forms of energy that are not easily storable. The load curve, which describes the evolution of electricity demand over different times during a year is approximated by a series of time-slices. For the moment, as it was the case for MARKAL models, we consider six (6) time-slices, which are: Summer-Day; Summer-Night, Intermediate-Day; Intermediate-Night, Winter-Day; Winter-Night. For low temperature heat, used in residential and commercial heating, a simpler load curve is considered. In addition, peak load reserve constraints can be introduced to impose that the energy system keeps enough capacity to face peak-load demand. 


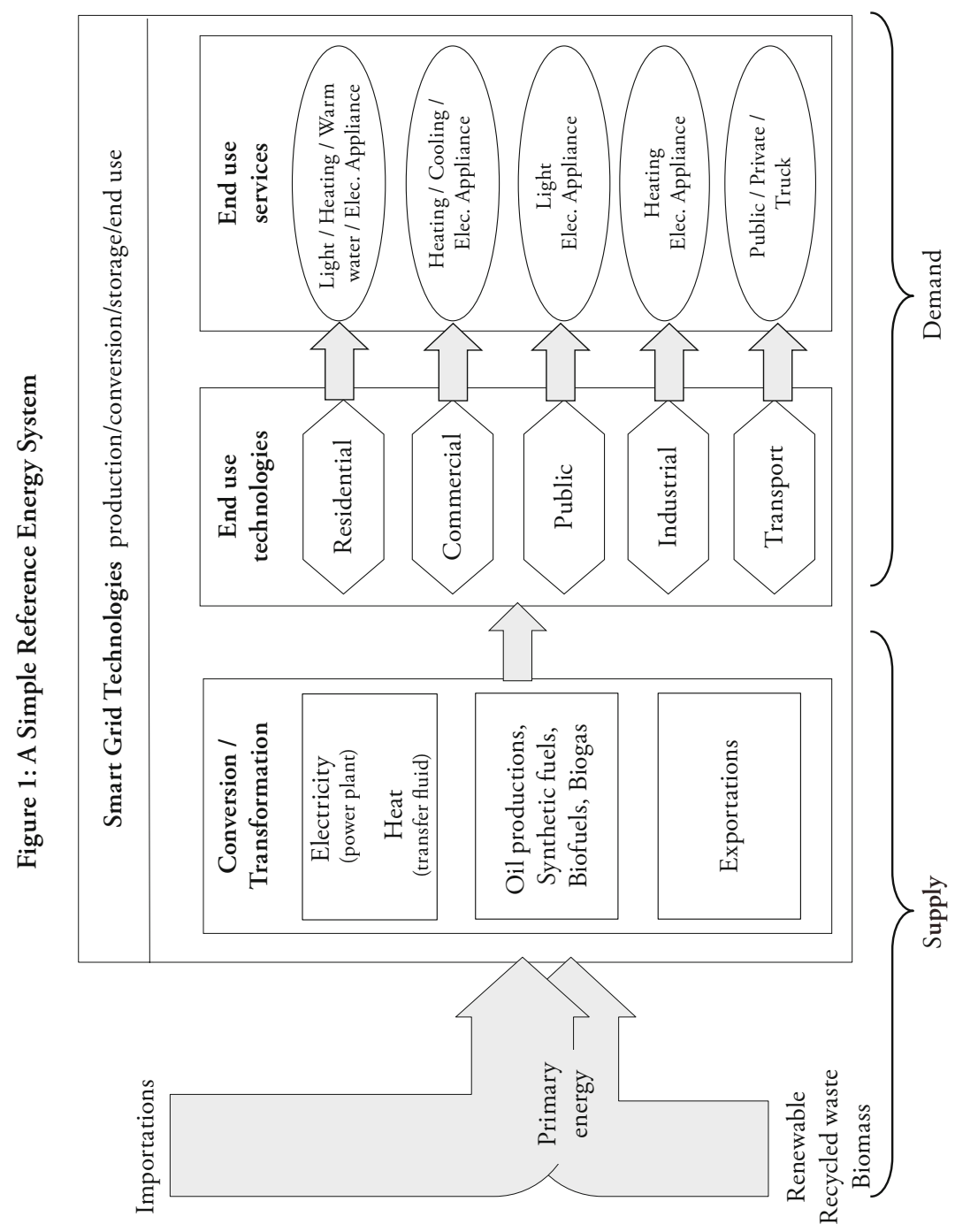


The main difference between a national or multi-national model, like TIMES, and a regional model like ETEM is in the emphasis given in the latter to the representation of demand technologies for residential and commercial heat, sanitary water, transportation (public and private) and captive electricity usages, whereas energy uses in industry, refineries and nuclear plants are not considered in full details. ETEM contains a detailed description of the distribution of electricity, natural gas and heat through networks. It can also give an accurate representation of the potential of renewable energy for decentralized electricity or heat production.

A few more details concerning the main equations of the model are given in the Annex. It suffices to say, for the moment, that ETEM is a linear programming model. It is very efficient for the description of economic activities that satisfy the diminishing marginal return paradigm, which corresponds to the use of convex cost functions or concave production functions. It permits also the modeling of increasing marginal returns, or concave cost function, through the introduction of mixed-integer programming optimization techniques.

\section{Representation of Smart Grid Technologies}

Smart grids allow smart energy management through the use of technologies with two-way communication abilities that are acting as consumption, storage or production units, depending on the location and time-slice of the load curve. The temporary electricity storage activity is currently performed by hydroelectric pumped-storage facilities. The announced penetration of electric or plug-in hybrid electric cars and of small gas fuel-cell with heat storage etc. will permit a further extension of the temporary storage activity provided a smart-grid environment exists. We describe below how we have represented in the model some of the demand technologies, for transport, residential and commercial heating and for renewable electricity production that can be linked together through a smart grid.

\subsection{Representation of Temporary Storage}

A temporary storage unit can store a commodity at some time-slices and deliver the same commodity, with some loss due to the storage, at another time-slice. A commodity, like electricity or heat is temporarily stored either for technical reasons (e.g, because the production is intermittent) or because of attractive (implicit) price differences between two different times in a day. We show now how to represent these activities of temporary storage in ETEM. 
We need to distinguish the demand technology from its storage capacity, when this capacity exists. So we create a commodity of storage between the demand technology and its storage unit. For example, the technology electric car is decomposed between the technology car and the technology battery. We distinguish the commodities electricity, electricity for storage, electricity for transport and represent their flows at different time-slices. We can then represent the use of batteries to provide the transportation service and also to contribute to the electricity system service, in particular to satisfy peak load demand. We show below how this technology is represented in the RES.

\subsection{Electric Vehicle}

We assume in this study that electric vehicles with their batteries can contribute to peak load reserve requirements in all time-slices; they also allow storage of electricity produced during low demand time-slice and to be used during the time-slice of highest demand. The techno-economic parameters of the electric vehicle have been defined in accordance with KемpтоN and Tomić, 2005. To model electric vehicle in ETEM, we adopt the approach illustrated in Figure 2. As indicated before, we decompose the electric vehicle technology into two separated technologies, i.e., vehicle and battery, with the constraint that the number of batteries is lower than three times the number of vehicles (some variations on this constraint will be discussed later). The input of both technologies is electricity while the outputs are different: vehicles produce a service of car tranport (measured in 1000 kilometer $\times$ vehicles per day) while batteries give an energy form: electricity (in PJ). The technology battery has a positive contribution to peak-load reserve constraints.

For the moment, we consider the option where the batteries are part of the car and loaded at home or in a parking. We consider that an electric car is equipped with a battery of $60 \mathrm{~kW}$ corresponding to $80 \mathrm{HP}$. The modeling of electric cars within ETEM relies on technological assumptions (as outlined below), where conservative parameter values are chosen, so that attractiveness of electric cars can not be overestimated. For batteries, we use an initial cost of $1700 \mathrm{CHF} / \mathrm{kWh}$ (in 2010) slowly going down to $250 \mathrm{CHF} / \mathrm{kWh}$ in 2030 , which corresponds roughly to ETSAP/IEA data. The cost of a typical electric car in ETEM is about $30,000 \mathrm{CHF}$ in 2020 (excluding the price of batteries which is about 8,000 CHF). The car efficiency is taken from the average value in ETSAP data, i.e. $0.7 \mathrm{MJ} /$ $\mathrm{km}$. We assume that $5 \%$ of batteries are available for storage or release, and that the quantity of energy in a fully charged battery is equal to $100 \mathrm{MJ}(27 \mathrm{kWh})$. Typically $30 \mathrm{~km}$ of travel in one day requires $20 \mathrm{MJ}$, so $80 \mathrm{MJ}$ are available 
Figure 2: Electric Vehicle Modeling in ETEM

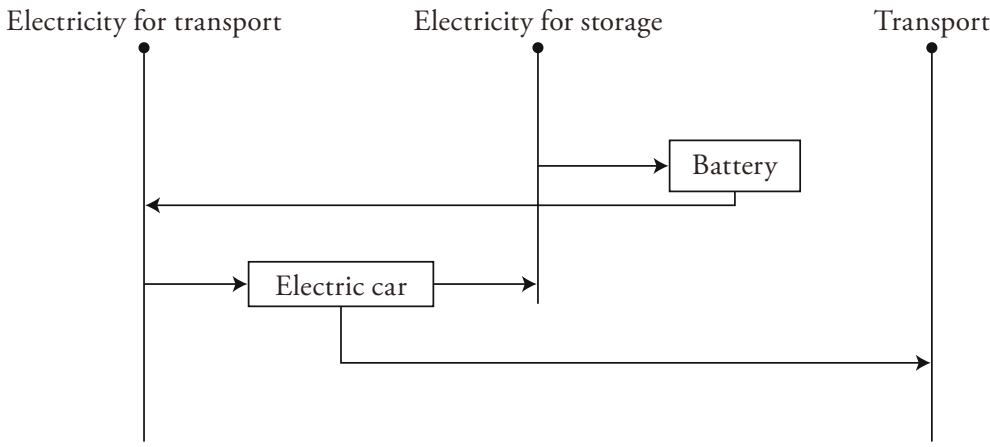

during the day for a release to the electric grid. In forthcoming implementations other options will be explored, for instance the option where an empty battery is replaced by a recharged one at a service station containing a lot of batteries that could also be used for temporary storage.

\subsection{Photovoltaic Units}

The representation of photovoltaic (PV) units is given in Figure 3. We assume here that all produced electricity is used directly for demand satisfaction and so $\mathrm{PV}$ units are not connected to storage technologies. The intermittent production is considered, with an availability of $10 \%$ in winter-day, $40 \%$ in summerday and $20 \%$ in intermediate-day while the availability of PV units is fixed at 0 during night time-slices. The life time of a PV is fixed at 30 years, and $25 \%$ of the capacity can contribute to the peak of consumption during the day. The cost of PV panels corresponds to a price of $0.17 \mathrm{CHF} / \mathrm{kWh}$.

\subsection{Wind Mills}

The representation of winds mills is given in Figure 4. The overall energy conversion efficiency is taken as $40 \%$. The intermittent production is considered, with an availability of $30 \%$ over a year. The life time of a wind mill is fixed at 25 years. The electricity produced by wind mills has a cost of $0.025 \mathrm{CHF} / \mathrm{kWh}$. 
Figure 3: Modeling of PV Units in ETEM

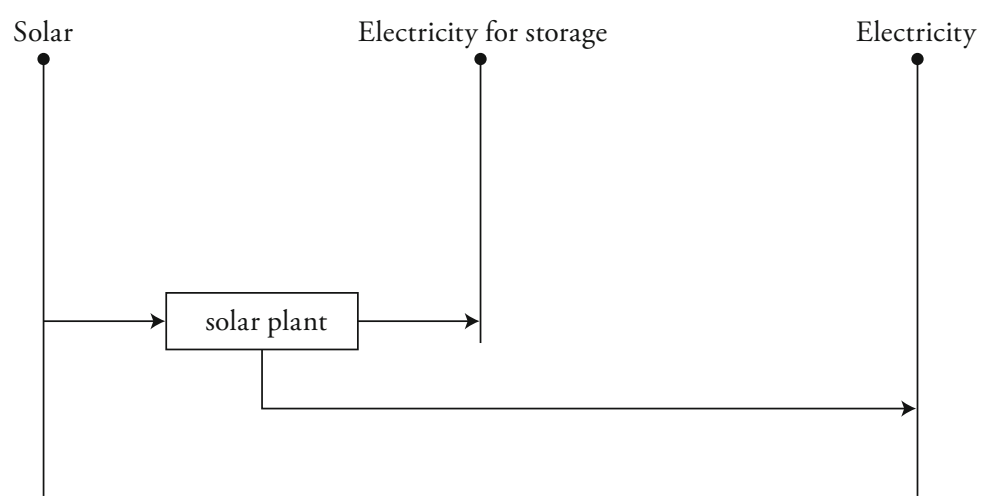

Figure 4: Modeling of Wind Mills in ETEM

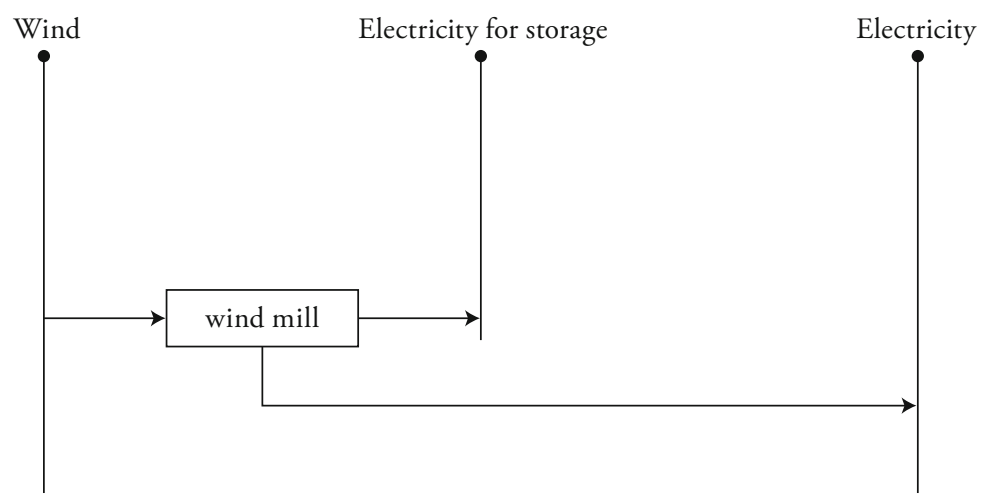

\subsection{Decentralized Combined Heat Power Production}

Among the new technologies that could link residential or commercial heating systems with smart grids, we have retained the small gas powered fuel cell combined heat power (CHP) with temporary storage of heat. These decentralized units (like e.g. those based on SOFC fuell-cells) can produce electricity during time-slices of high demand and store the heat for use during the rest of the day. They are considered as promising contributors to a rationalization of 
both electric and gas grids (Acha, Green, and Shah, 2010b; Streckiene et al., 2009). Within ETEM, the cost of such production unit is taken as 1,000 Millions of CHF per GW starting from 2015, with a maximum of $35 \%$ of electricity (and a minimum of $65 \%$ of heat). We base our cost evaluation on Huang, Zhang, and Jiang (2006), Brown, Hendry, and Harborne (2007), Neef (2009), and Hawkes and Leach (2007). We expect prices to drop by 2015 (see e.g. http://wwwl.eere.energy.gov/hydrogenandfuelcells/fuelcells/systems.html). As well, data coming from manufacturers when available (Panasonic, CERES power) and from large-scale tests in Japan are used.

Figure 5: CHP Modeling in ETEM

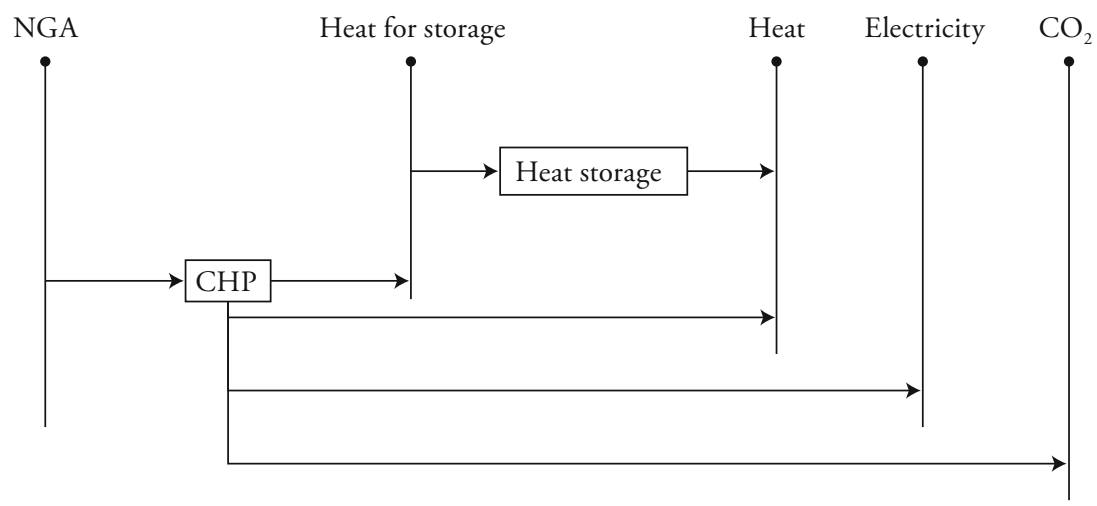

\subsection{Geothermal Units}

Geothermal units could be used also for CHP production with storage of heat. However, in this modeling exercise we only kept the technology using low depth heat, which only produces residential or commercial heat. Within ETEM, the cost of geothermal unit is equal to $1,200 \mathrm{CHF} / \mathrm{GW}^{3}$.

3 As stated in Hirschberg, Wokaun, and Bauer (2005), this cost is highly speculative. 
Figure 6: Geothermal Units Modeling in ETEM

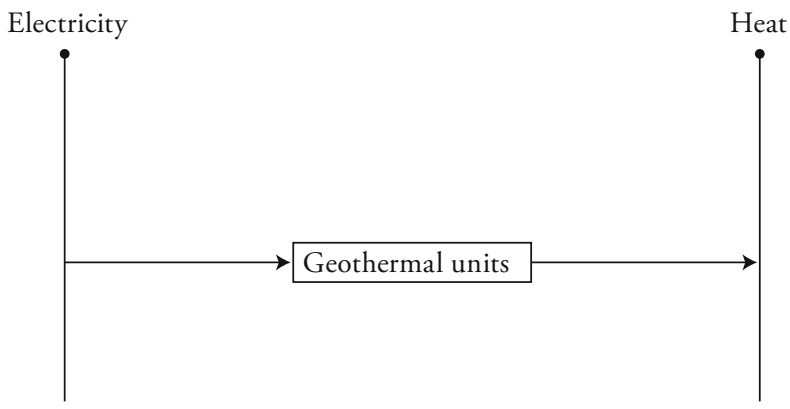

This simple geothermal unit is a decentralized renewable technology, which will not benefit from a two-way communication system and will not contribute to the electricity system service.

\section{Scenario Analysis}

\subsection{Application to Geneva}

In this section we develop an example of the use of ETEM to analyze a long term evolution scenario for the energy system of an urban region of size and characteristics similar to Geneva. Although we tried to replicate as much as possible the current features of the Geneva energy production, import and consumption system, this scenario analysis should not be considered as an indication of any official energy plan. The purpose of this analysis is uniquely exploratory and, as discussed in the conclusion, much more has to be added to the model to fully grasp the constraints and opportunities associated with smart-grid developments. We detail in the next subsections some important data ${ }^{4}$.

4 Other data, like technology specificities for instance, are mainly calibrated with ETSIAP, IEA and cantonal offices of statistics and energy. 


\subsection{Useful Demand and Imported Energy Price Projections}

\subsubsection{Demands}

Table 1 summarizes the assumptions on useful demands. We assume the typical building and housing replacement rate of $1 \%$ generally accepted in European cities.

Table 1: Useful Demands (PJ/Y or ${ }^{*}=1000 \mathrm{~km} \times$ Vehicle/Day)

\begin{tabular}{|c|c|c|c|c|c|c|c|c|}
\hline time periods & 2010 & 2015 & 2020 & 2025 & 2030 & 2035 & 2040 & 2045 \\
\hline El. Industrial & 0.74 & 0.82 & 0.90 & 1.00 & 1.10 & 1.21 & 1.34 & 1.48 \\
\hline El. Residential & 0.74 & 0.82 & 0.90 & 1.00 & 1.10 & 1.21 & 1.34 & 1.48 \\
\hline El. commercial & 1.81 & 1.90 & 2.00 & 2.10 & 2.21 & 2.32 & 2.44 & 2.56 \\
\hline El. Public Use & 4.65 & 5.13 & 5.67 & 6.26 & 6.91 & 7.63 & 8.42 & 9.30 \\
\hline El. Public Light & 1.33 & 1.40 & 1.47 & 1.55 & 1.63 & 1.71 & 1.80 & 1.89 \\
\hline LTH Industrial Area & 0.13 & 0.13 & 0.14 & 0.15 & 0.15 & 0.16 & 0.17 & 0.18 \\
\hline $\begin{array}{l}\text { Heat Buildings } \\
2-9 \text { appts. }\end{array}$ & 12.91 & 14.64 & 15.81 & 16.62 & 17.47 & 18.36 & 19.29 & 20.28 \\
\hline Heat Houses & 1.56 & 1.63 & 1.72 & 1.81 & 1.90 & 1.99 & 2.10 & 2.20 \\
\hline $\begin{array}{l}\text { Warm Water for } \\
\text { Buildings }\end{array}$ & 4.36 & 4.58 & 4.82 & 5.06 & 5.32 & 5.59 & 5.88 & 6.18 \\
\hline $\begin{array}{l}\text { Warm Water for } \\
\text { Houses }\end{array}$ & 0.40 & 0.42 & 0.44 & 0.46 & 0.49 & 0.51 & 0.54 & 0.57 \\
\hline $\begin{array}{l}\text { * Public Transports: } \\
\text { Bus }\end{array}$ & 73.85 & 77.62 & 81.58 & 85.74 & 90.12 & 94.71 & 99.54 & 104.62 \\
\hline $\begin{array}{l}\text { * Public Transports: } \\
\text { Tramway }\end{array}$ & 10.51 & 11.05 & 11.61 & 12.20 & 12.82 & 13.48 & 14.17 & 14.89 \\
\hline $\begin{array}{l}\text { * Public Transports: } \\
\text { Train }\end{array}$ & 7.36 & 7.73 & 8.13 & 8.54 & 8.98 & 9.43 & 9.92 & 10.42 \\
\hline $\begin{array}{l}\text { * Public Transports } \\
\text { Misc. }\end{array}$ & 1.05 & 1.10 & 1.16 & 1.22 & 1.28 & 1.35 & 1.42 & 1.49 \\
\hline${ }^{*}$ Automobile & 7231 & 7600 & 7987 & 8395 & 8823 & 9273 & 9746 & 10243 \\
\hline * Truck & 88 & 93 & 97 & 102 & 107 & 113 & 119 & 125 \\
\hline${ }^{*}$ Delivery vehicles & 313 & 329 & 346 & 364 & 382 & 402 & 422 & 444 \\
\hline
\end{tabular}


Except for transportation, we represent the demand for energy services by the amount of energy used during a year. The demands of transport are represented in 1000 s vehicle $\times \mathrm{km}$ per day.

In order to project the demand evolution ${ }^{5}$ over the time horizon of 2045 we use two drivers: (i) a GDP driver assumed to be growing at $2 \%$ per year (for industrial and commercial electricity and commercial heat); (ii) a demographic driver assumed to be growing at $1 \%$ per year (for remaining demands). The population of the region considered is 460,000 in 2010 .

\subsubsection{Energy Prices}

The second set of important drivers of the model concerns the evolution of energy prices. For end-use prices in 2005 and 2010, we use IEA (2011a) valid for Switzerland including taxes. On top of that, we use projections for fossil fuels that are consistent with those proposed by IEA (2011b). Figures 7-8 summarize these assumptions. The prices are given in million-CHF per PJ ( $\mathrm{Mfr} / \mathrm{PJ})$.

For electricity we distinguish two price levels, a high one during day time-slices (from $50 \mathrm{MCHF} / \mathrm{PJ}$ in 2010 to $95 \mathrm{MCHF} / \mathrm{PJ}$ in 2045) and a lower one during night time-slices (from $26 \mathrm{MCHF} / \mathrm{PJ}$ in 2010 to $52 \mathrm{MCHF} / \mathrm{PJ}$ in 2045). These price schedules include taxes and are consistent with those proposed in the companion paper (Weidmann, Kannan, and Turton, 2012, which analyses the electricity sector in Switzerland.

\subsection{Residual Capacities and Calibration on Year 2010}

\subsubsection{Identification of Residual Capacities}

The model takes into account the technologies that are already installed and their remaining life time, based on assumptions on average technologies efficiencies ${ }^{6}$ and cantonal data available for the Geneva Canton OFSTAT-GE (2005-2010). Tables 2-4 provide a description of the main technology choices that are currently made in this region to produce electricity and heat and to satisfy the useful demands. We make the distinction between existing and new buildings. The term "new" means all buildings constructed since 1995.

5 The demands are exogenous. The computation with drivers are made before modeling.

6 Using ETSAP-IEA data (http://www.iea-etsap.org/web/Demand.asp) and other sources. 
Figure 7: Energy Prices (in Mfr/PJ)
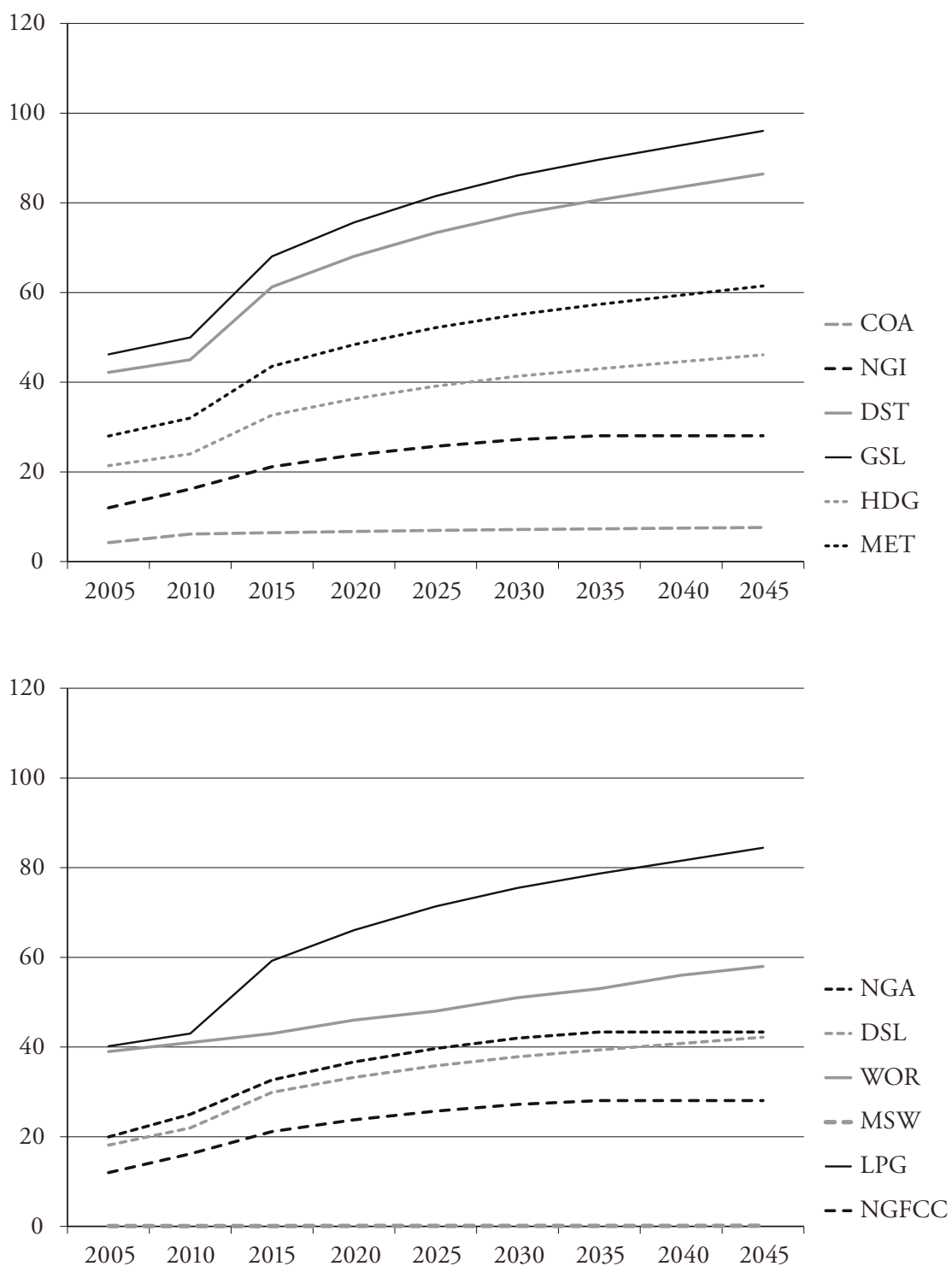


\section{Figure 8: Electricity Prices (Mfr/PJ)}

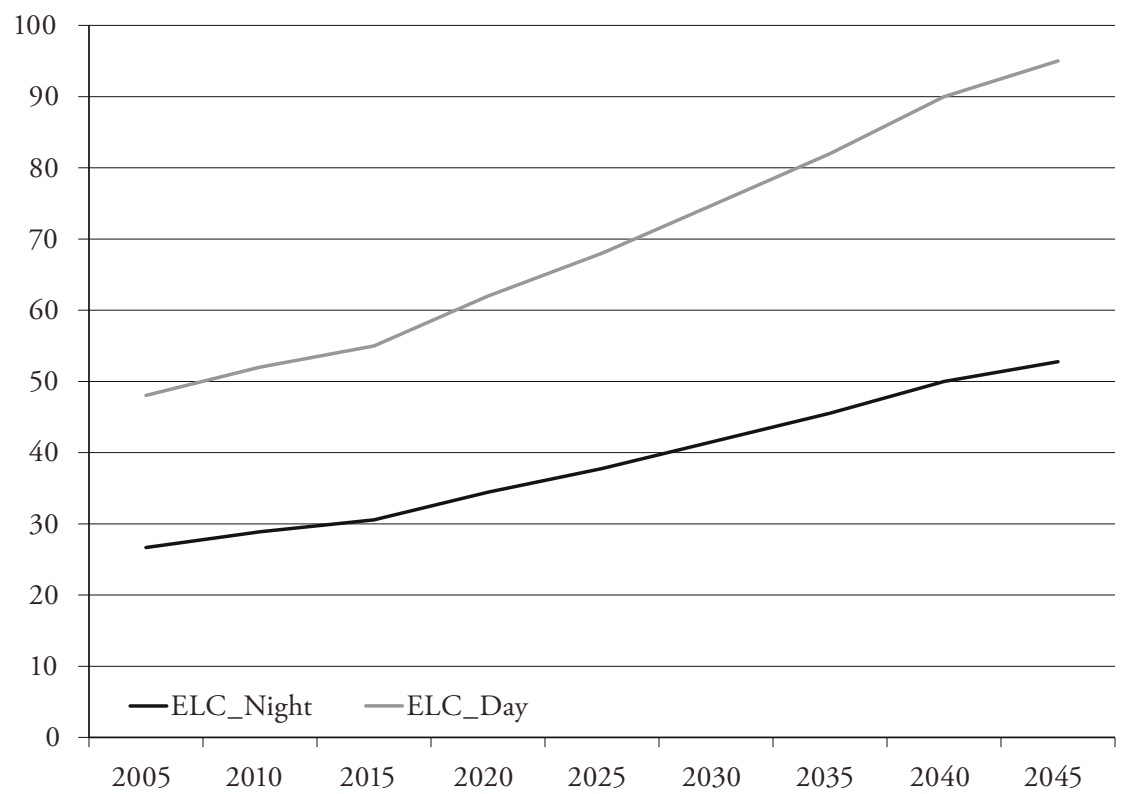

Table 2: Residual Capacities: Heat and Warm Water (PJ/Y)

\begin{tabular}{lccccccccc}
\hline & 2010 & 2015 & 2020 & 2025 & 2030 & 2035 & 2040 & 2045 \\
\hline $\begin{array}{l}\text { Eil furnace heat } \\
\text { \& warm water }\end{array}$ & 0.0247 & 0.0212 & 0.0176 & 0.0141 & 0.0106 & 0.007 & 0.0035 & 0 \\
$\begin{array}{l}\text { Gas furnace heat } \\
\text { \& warm water }\end{array}$ & 0.0439 & 0.0376 & 0.0063 & 0.0051 & 0.0038 & 0.0025 & 0.0013 & 0 \\
\hline $\begin{array}{l}\text { Existing houses } \\
\begin{array}{l}\text { Oil furnace heat } \\
\text { \& warm water }\end{array}\end{array}$ & 0.2191 & 0.1799 & 0.1481 & 0.1463 & 0.1145 & 0.0827 & 0.0508 & 0 \\
$\begin{array}{l}\text { Gas furnace heat } \\
\text { \& warm water }\end{array}$ & 0.2655 & 0.2424 & 0.2238 & 0.1853 & 0.1367 & 0.0981 & 0.0395 & 0 \\
Gas furnace & 0.0940 & 0.0686 & 0.0571 & 0.0457 & 0.0343 & 0.0229 & 0.0114 & 0 \\
\hline
\end{tabular}


Table 2 continued

\begin{tabular}{|c|c|c|c|c|c|c|c|c|}
\hline & 2010 & 2015 & 2020 & 2025 & 2030 & 2035 & 2040 & 2045 \\
\hline \multicolumn{9}{|c|}{ New buildings } \\
\hline $\begin{array}{l}\text { Oil furnace } \\
\text { heat } \& \text { warm water }\end{array}$ & 0.1389 & 0.118 & 0.0944 & 0.076 & 0.057 & 0.038 & 0.019 & 0.01 \\
\hline \multicolumn{9}{|c|}{ Warm Water Buildings } \\
\hline Elect. warm water & 0.0334 & 0.025 & 0.022 & 0.015 & 0.013 & 0 & 0 & 0 \\
\hline Gas warm water & 0.0334 & 0.025 & 0.022 & 0.015 & 0.013 & 0 & 0 & 0 \\
\hline \multicolumn{9}{|c|}{ Warm Water houses } \\
\hline Elect. warm water & 0.0317 & 0.0273 & 0.0218 & 0.0175 & 0.0134 & 0.089 & 0.0445 & 0 \\
\hline
\end{tabular}

Table 3: Residual Capacities: Transport $(1000 \mathrm{~km} \times$ Vehicle / Day $)$

\begin{tabular}{|c|c|c|c|c|c|c|c|c|}
\hline & 2010 & 2015 & 2020 & 2025 & 2030 & 2035 & 2040 & 2045 \\
\hline \multicolumn{9}{|c|}{ Public Transport } \\
\hline Diesel Bus & 66.23 & 26.6 & 10.7 & 4.3 & 1.8 & 0.7 & 0 & 0 \\
\hline Trolleybus & 7.64 & 3.82 & 1.15 & 0.46 & 0 & 0 & 0 & 0 \\
\hline Tramway & 15.2 & 8.9 & 5.3 & 3.1 & 0 & 0 & 0 & 0 \\
\hline Train & 15.6 & 9.2 & 5.4 & 3.2 & 0 & 0 & 0 & 0 \\
\hline Miscellaneous & 1.51 & 0.5 & 0 & 0 & 0 & 0 & 0 & 0 \\
\hline \multicolumn{9}{|c|}{ Private Transport } \\
\hline Diesel car & 1228 & 600 & 186 & 74 & 0 & 0 & 0 & 0 \\
\hline Gasoline car & 6003 & 3000 & 909 & 360 & 0 & 0 & 0 & 0 \\
\hline \multicolumn{9}{|c|}{ Trucks } \\
\hline Diesel truck & 88.1 & 41.9 & 0 & 0 & 0 & 0 & 0 & 0 \\
\hline \multicolumn{9}{|c|}{ Delivery vehicles } \\
\hline Light diesel truck & 63 & 31.09 & 0 & 0 & 0 & 0 & 0 & 0 \\
\hline Light gasoline truck & 251 & 150.28 & 0 & 0 & 0 & 0 & 0 & 0 \\
\hline
\end{tabular}


Table 4: Residual Capacities: Centralised Conversion Technologies (MW)

\begin{tabular}{lcccccccc}
\hline Type, Location & 2010 & 2015 & 2020 & 2025 & 2030 & 2035 & 2040 & 2045 \\
\hline Hydro, Chancy-Pougny & 44 & 44 & 44 & 53 & 53 & 53 & 53 & 53 \\
Hydro, Seujet & 5.5 & 5.5 & 5.5 & 5.5 & 5.5 & 5.5 & 5.5 & 5.5 \\
Hydro, Vessy & 0.25 & 0.25 & 0.25 & 0.25 & 0.25 & 0.25 & 0.25 & 0.25 \\
Hydro, Project Conflan & 0 & 0 & 0 & 0 & 25 & 25 & 25 & 25 \\
Photovoltaic, Total & 12 & 15 & 15 & 7 & 3 & 0 & 0 & 0 \\
Wind, Total & 1 & 56 & 56 & 56 & 56 & 56 & 0 & 0 \\
$\begin{array}{l}\text { Municipal waste CHP, } \\
\text { Cheneviers }\end{array}$ & 40 & 40 & 40 & 40 & 40 & 40 & 40 & 40 \\
Hydro, Verbois & 98 & 98 & 98 & 98 & 98 & 98 & 98 & 98 \\
\hline
\end{tabular}

\subsubsection{Calibration in 2010}

From the residual capacities of current technologies and their technical coefficients describing input and output of commodities, we can compute the share of different energy forms in the primary energy balance, the use of different energy forms by end-use sectors and the energy imports (see Figures 9-11). These figures show that the model is correctly calibrated on the situation prevailing in the canton of Geneva in 2010.

Figure 9: Distribution of Primary Energy Forms for Geneva in 2010 (in\%).

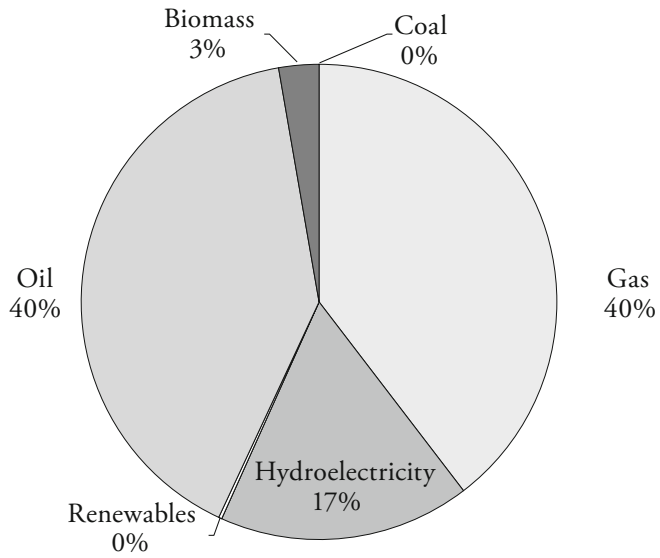


Figure 10: Distribution of Energy Consumption by End-Use Sectors for Geneva in 2010 (in\%).

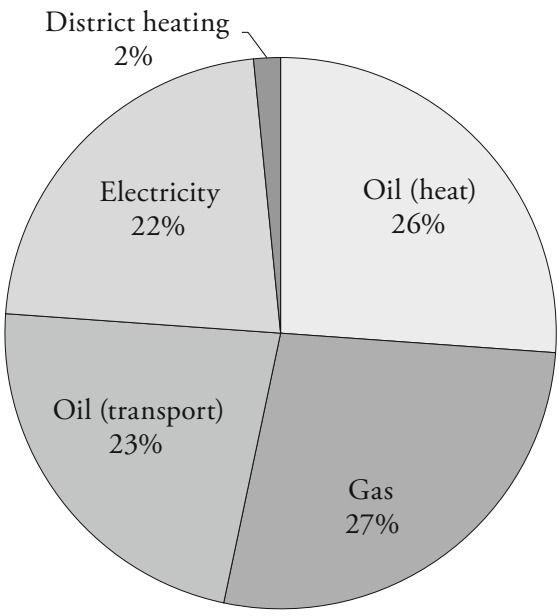

Figure 11: Distribution of Energy Imports for Geneva in 2010 (in\%).

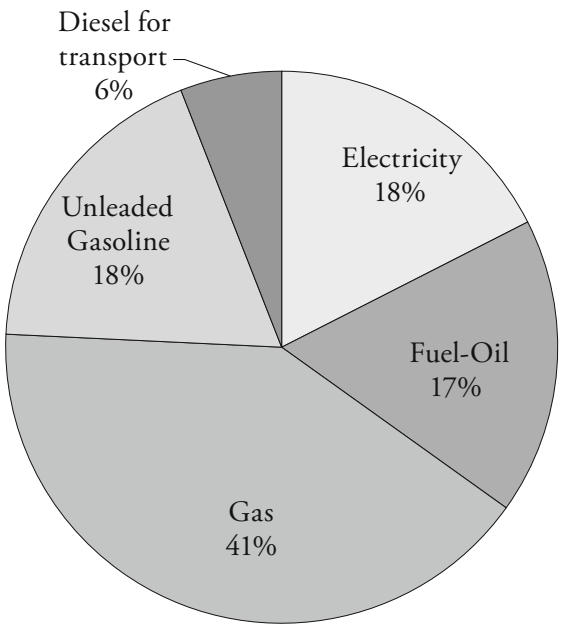




\subsection{Assessing New Technology Impacts on Three Contrasted Scenarios}

In this subsection, we compare the energy system evolutions of the Geneva canton on three contrasted scenarios and we highlight the role of renewable and smartgrid technologies in those evolutions.

\subsection{1 $\mathrm{CO}_{2}$ Emission Targets}

The three scenarios differ by their $\mathrm{CO}_{2}$ emission targets and the limit imposed on electricity imports. The BAU scenario has no limitation on GHG emissions and no restriction concerning electricity imports. The Factor- 4 scenario aims at a reduction by 4 of the current emission levels $\left(2 \mathrm{Mt} \mathrm{CO}_{2}\right)$. The objective is thus to decrease to $0.4 \mathrm{Mt} \mathrm{CO}_{2}$ in 2045 . The Regulation scenario aims at limiting the electricity imports at $15 \mathrm{PJ} /$ Year (corresponding roughly to 50\% of the electricity imports in scenario Factor-4) and reducing the GHG emissions to $1.25 \mathrm{Mt}$ $\mathrm{CO}_{2}$. These three targets are represented in Figure 12.

Figure 12: Emissions in Mt of CO2 Equivalent for the Three Contrasted Scenarios.

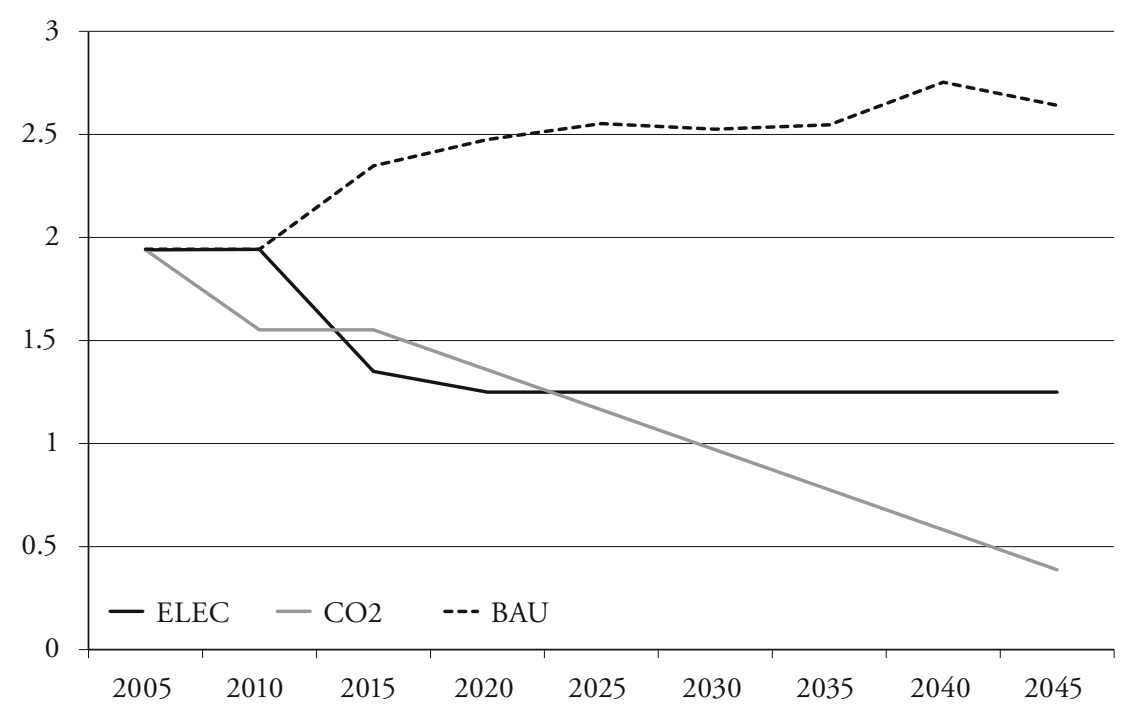




\subsection{BAU Scenario}

In the Business as usual (BAU) scenario, GHG emission reaches a value close to $2.7 \mathrm{MtC} / \mathrm{Y}$ of $\mathrm{CO}_{2}$ in 2040 . This is explained partly by the stable contribution of oil (to be used mainly in transport) and the strong penetration of gas in the primary energy balance, as shown in Figure 13.

Figure 13: Primary Energy (PJ/Year) - BAU Case.

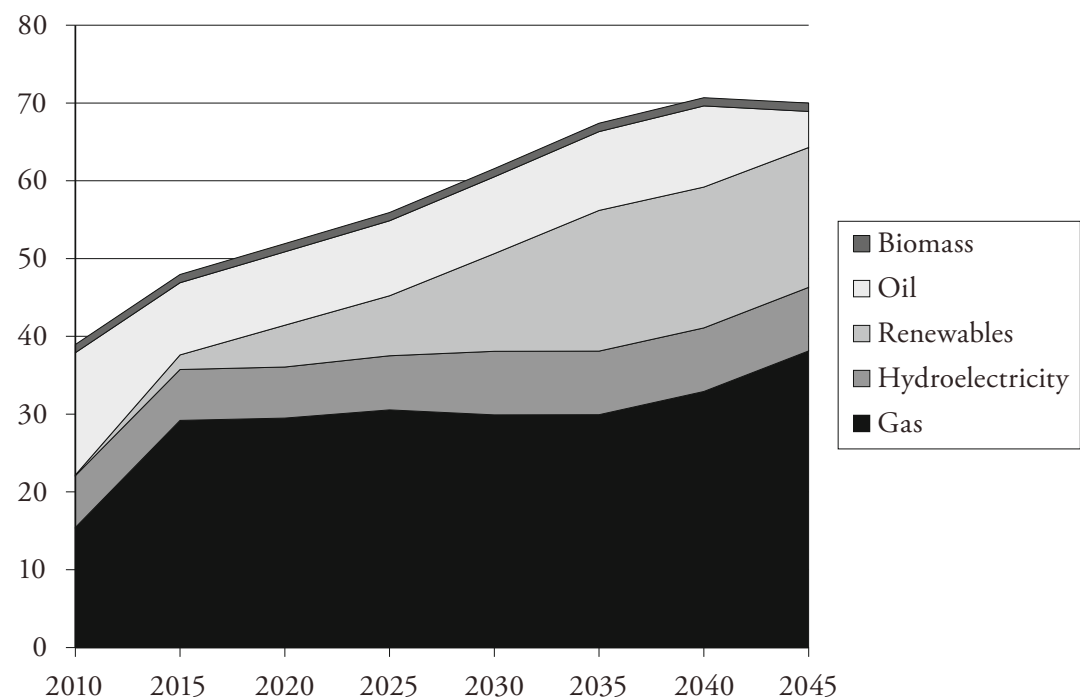

Among renewable technologies, wind mills penetrate strongly to reach the imposed limit of $0.5 \mathrm{GW}$ of installed capacity in 2035. The $0.5 \mathrm{GW}$ limit corresponds to the current estimate of the region potential for wind technology development. However storage facilities are not installed, since electric cars do not penetrate, except in the very last period (2045). Small gas fuell cell CHP decentralized units with storage penetrate in the new building sector. 
Table 5: Centralized Conversion Technologies (MW)

\begin{tabular}{lcccccccc}
\hline Type, Location & 2010 & 2015 & 2020 & 2025 & 2030 & 2035 & 2040 & 2045 \\
\hline Hydro, Chancy-Pougny & 44 & 44 & 44 & 53 & 53 & 53 & 53 & \multicolumn{1}{c}{53} \\
Hydro, H. Project Seujet & 5.5 & 5.5 & 5.5 & 5.5 & 5.5 & 5.5 & 5.5 & \multicolumn{1}{c}{5.5} \\
Hydro, H. Vessy & 0.25 & 0.25 & 0.25 & 0.25 & 0.25 & 0.25 & 0.25 & 0.25 \\
Hydro, H. Conflan & 0 & 0 & 0 & 0 & 25 & 25 & 25 & 25 \\
Photovoltaic, Total & 12 & 15 & 15 & 7 & 3 & 0 & 0 & 62 \\
District heat, Total & 25 & 16 & 16 & 16 & 16 & 16 & 16 & 16 \\
Heat and electricity plant, & 40 & 40 & 40 & 40 & 40 & 40 & 40 & 40 \\
Cheneviers & & & & & & & & \\
Gas CC & 0 & 245 & 245 & 245 & 245 & 245 & 215 & 215 \\
Gas turbine & 43.6 & 43.6 & 43.6 & 0 & 0 & 0 & 0 & 0 \\
Hydro, Hydro Verbois & 98 & 98 & 98 & 98 & 98 & 98 & 98 & 98 \\
Wind mills, Total & 1 & 56 & 200 & 300 & 500 & 500 & 500 & 500 \\
\hline
\end{tabular}

Table 6: Heat Technologies, New Buildings (MW)

\begin{tabular}{lrrrrrrrr}
\hline & 2010 & 2015 & 2020 & 2025 & 2030 & 2035 & 2040 & 2045 \\
\hline $\begin{array}{l}\text { Oil furnace, heat } \\
\text { \& warm water }\end{array}$ & 138.9 & 118 & 94 & 76 & 57 & 38 & 19 & 10 \\
Gas furnace & 37 & 37 & 58 & 74 & 36 & 36 & 15 & 0 \\
Geothermal & 0 & 100 & 100 & 100 & 100 & 100 & 100 & 100 \\
Small CHP & 0 & 120 & 227 & 301 & 307 & 618 & 676 & 706 \\
\hline
\end{tabular}

Table 7: Heat Technologies, Existing Buildings (MW)

\begin{tabular}{lcccccccc}
\hline & 2010 & 2015 & 2020 & 2025 & 2030 & 2035 & 2040 & 2045 \\
\hline $\begin{array}{l}\text { Oil furnace, heat } \\
\text { \& warm water }\end{array}$ & 219 & 179 & 148 & 146 & 114 & 83 & 51 & 0 \\
Gas furnace & 360 & 311 & 316 & 292 & 366 & 440 & 439 & 386 \\
District-heat & 8.5 & 8.5 & 8.5 & 8.5 & 8.5 & 8.5 & 8.5 & 8.5 \\
Small CHP & 0 & 400 & 417 & 417 & 417 & 77 & 146 & 323 \\
\hline
\end{tabular}


Wind is the largest part of renewables (excepted hydro) in the primary balance. Two factors can explain the strong contribution of wind. First, the availability factor (i.e. equivalent percentage of full usage days), which is set to $30 \%$ and the conversion efficiency, which is set to $40 \%$ (this includes efficiencies of conversion of wind energy into mechanical energy and the efficiency of electric generation).

In the end-use sectors, consumption of electricity is maintained. Diesel car becomes the privileged choice for private transport and gas heating prevails in residential and commercial sectors.

In summary, a BAU scenario shows the competitiveness of wind for electricity production, a strong penetration of natural gas for space heating (replacing fuel oil), and the continuous use of oil for transportation, in more efficient gasoline cars. The high cost of electricity facilitates the penetration of small CHP units in existing and new buildings.

\subsection{Factor-4 Scenario: Strong Abatement for $\left(\mathrm{CO}_{2}\right)$ Emissions}

When we restrict severely the GHG emissions, electric cars penetrate strongly from year 2020 on and replace totally the diesel cars in 2030 (see Table 8).

Table 8: Private Transport $(1000 \mathrm{~km} \times$ Vehicle / Day $)$

\begin{tabular}{lrrrrrrrr}
\hline & 2010 & 2015 & 2020 & 2025 & 2030 & 2035 & 2040 & 2045 \\
\hline Diesel car & 1228 & 4599 & 4299 & 200 & 0 & 0 & 0 & 0 \\
Gasoline car & 6003 & 3000 & 600 & & 0 & 0 & 0 & 0 \\
Elec. car & 0 & 0 & 3087 & 8394 & 8823 & 9273 & 9746 & 10243 \\
\hline
\end{tabular}

The use of batteries to store energy is developing at the same time as electric cars penetrate the private transport sector. Table 9 illustrates the use of batteries during winter for the time period 2040-2044. During the night, electricity is stored (more than $80 \%$ of the consumption) and used during the day for transport but also injected in the electricity network. This allows the system to take advantage of low price of electricity during night. A similar storage, from night to day, is observed for each season. 
Figure 14: Energy Consumption by End-Use Sectors (PJ/Y) - BAU Case.

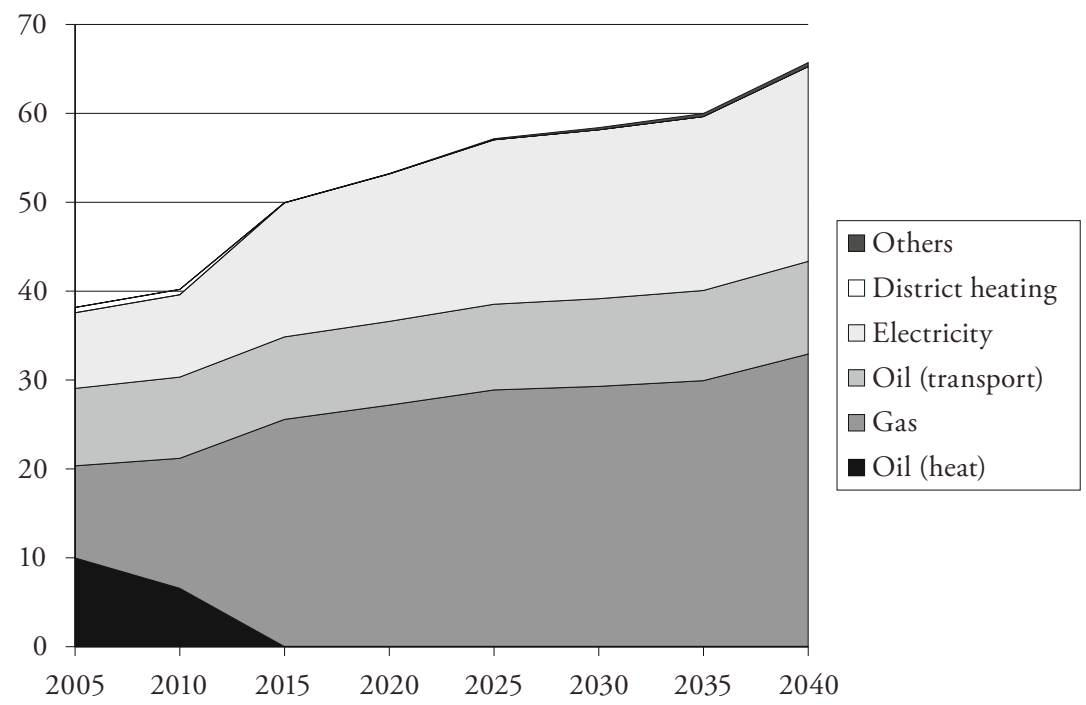

Figure 15: Energy Imports (PJ/Y) - BAU Case.

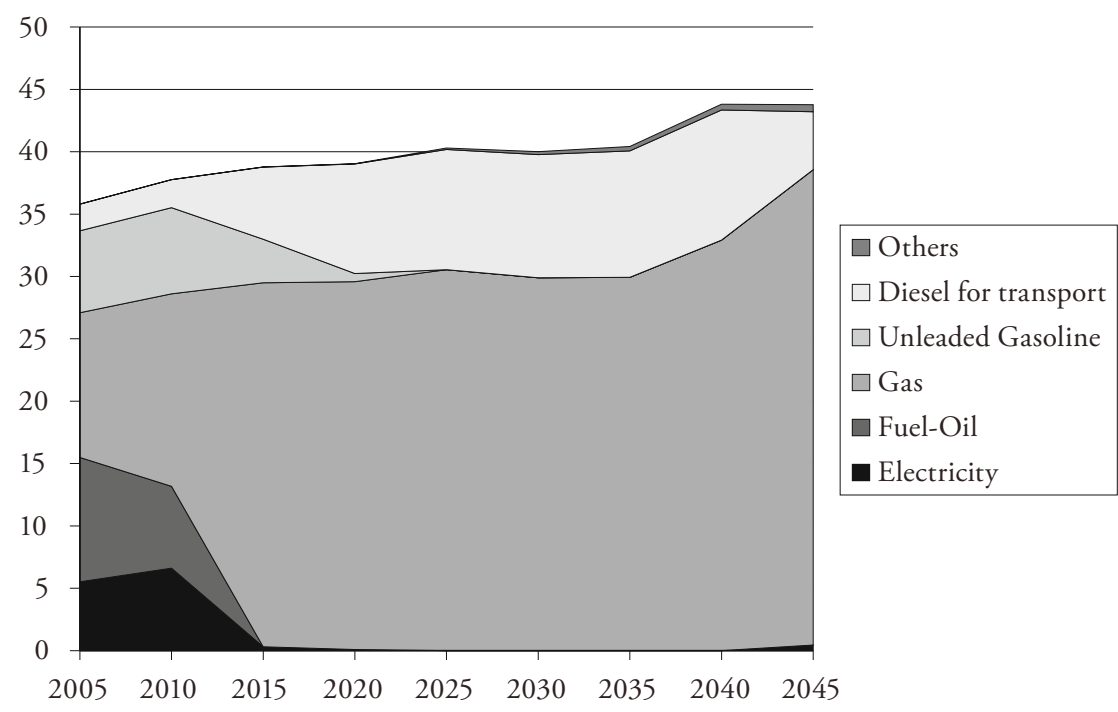


Table 9: Electric Vehicle Battery Activity (in PJ). Example in Winter 2040.

\begin{tabular}{lll}
\hline & Day & Night \\
\hline consumption from network & 0 & 6.40 \\
release of stored electricity & 5.88 & 0 \\
usage for transport & 0.82 & 0.41 \\
usage for storage & 0 & 5.88 \\
usage for network & 3.88 & 0 \\
storage loss $(20 \%)$ & 1.18 & 0.10 \\
\hline
\end{tabular}

Wind mills and solar PV units penetrate and reach their capacity limit of 500 MW in 2035 (Table 10).

Table 10: Renewable Electricity Capacities (MW)

\begin{tabular}{lrrrrrrrr}
\hline & 2010 & 2015 & 2020 & 2025 & 2030 & 2035 & 2040 & 2045 \\
\hline Photovoltaic & 12 & 15 & 15 & 7 & 3 & 500 & 500 & 500 \\
Wind & 1 & 56 & 200 & 300 & 500 & 500 & 500 & 500 \\
\hline
\end{tabular}

The end-use energy balance shows the progress of electricity consumption (Figure 16). This electricity is mostly obtained by increasing the electricity imports, which is considered carbon neutral in this scenario (Figure 17).

In summary, the factor 4 scenario maximizes the penetration of electricity, using intensively wind, solar and import sources. Electric cars penetrate and contribute importantly to a leveling of demand through a storage activity from night to day.

\subsection{Regulation Scenario: Limits on Electricity Imports and $\mathrm{CO}_{2}$ Emissions}

In this scenario we recognize that the decrease in GHG emissions should not be obtained by a large increase in electricity imports, since only a part of these imports is made of "green" electricity. Therefore we limit the imports to $15 \mathrm{PJ} / \mathrm{Y}$, whereas we limit the long term GHG emissions to $1.75 \mathrm{Mt} \mathrm{CO}_{2}$. Notice that 
Figure 16: Energy Consumption by End-Use Sectors (PJ/Y) - Factor 4 Case.

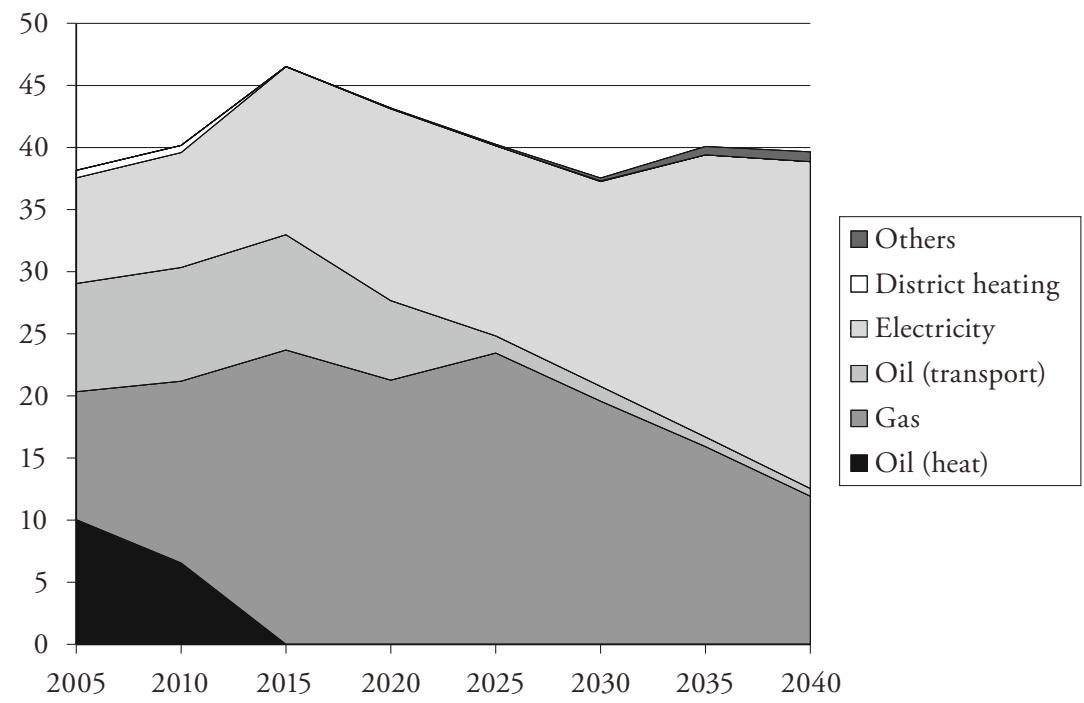

Figure 17: Energy Imports (PJ/Y) - Factor 4 Case.

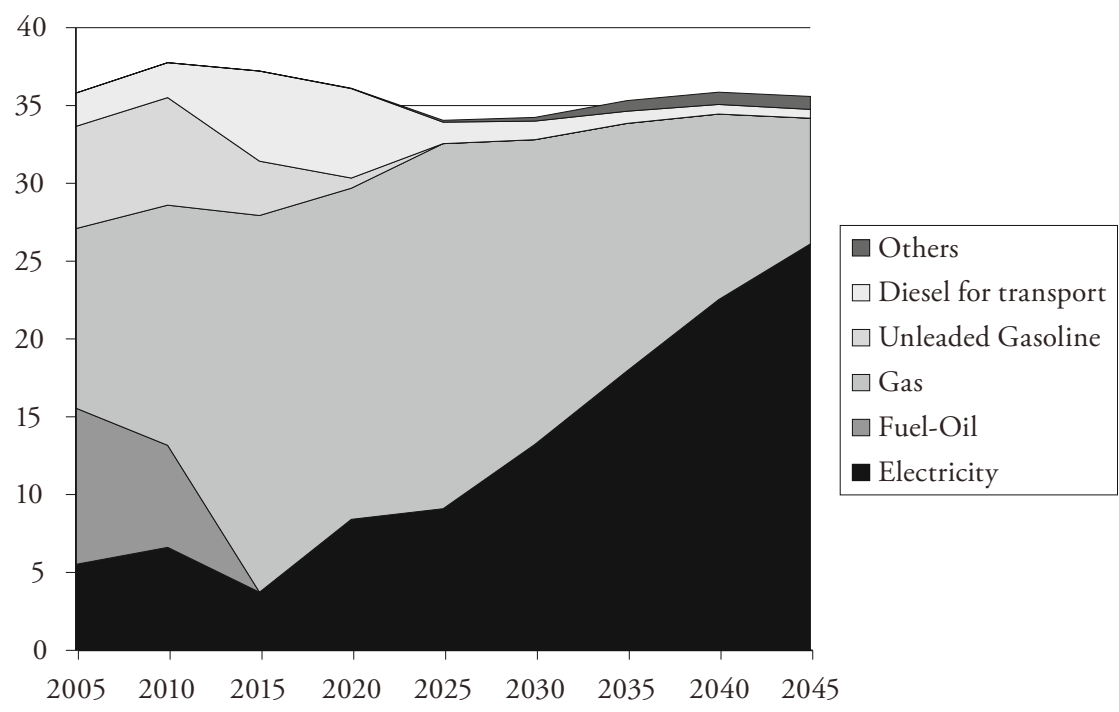


another possible approach would have been to estimate the carbon footprint of imported electricity and including it in the GHG emission balance.

Table 11: Car Capacities (1000 km $\times$ Vehicle per Day)

\begin{tabular}{lrrrrrrrr}
\hline & 2010 & 2015 & 2020 & 2025 & 2030 & 2035 & 2040 & 2045 \\
\hline Diesel car & 1228 & 4599 & 4299 & 2215 & 2311 & 95 & 0 & 0 \\
Gasoline car & 6003 & 3000 & 600 & 0 & 0 & 0 & 0 & 0 \\
Electric car & 0 & 0 & 3087 & 6178 & 6512 & 9178 & 9746 & 10243 \\
\hline
\end{tabular}

As shown in Table 11 the electric car tends to be the major technology used for private transport near the end of the time horizon although it only slowly replaces totally the diesel car usage. This behavior is the consequence of both the mitigation goal and the bounding of imports. To produce more efficiently, one imports electricity during night at low price and distributes the electricity during the day as shown in Table 12.

Table 12: Electric Vehicle Battery Activity (in PJ). Example in Winter 2040.

\begin{tabular}{lll}
\hline & Day & Night \\
\hline consumption from network & 0 & 3.86 \\
release of stored electricity & 3.34 & 0 \\
usage for transport & 0.82 & 0.41 \\
usage for storage & 0 & 3.34 \\
usage for network & 1.84 & 0 \\
storage loss $(20 \%)$ & 0.68 & 0.10 \\
\hline
\end{tabular}

In Figure 18 we can observe that the use of electricity remains moderate in the end-use sectors, whereas natural gas replaces totally oil for space heating.

This is also shown in the energy imports (Figure 19). In the space heating sector, the small CHP units penetrate again in 2015, as shown in Table 13. 
Figure 18: Energy Consumption by End-Use Sectors (PJ/Y) - Regulation Case.

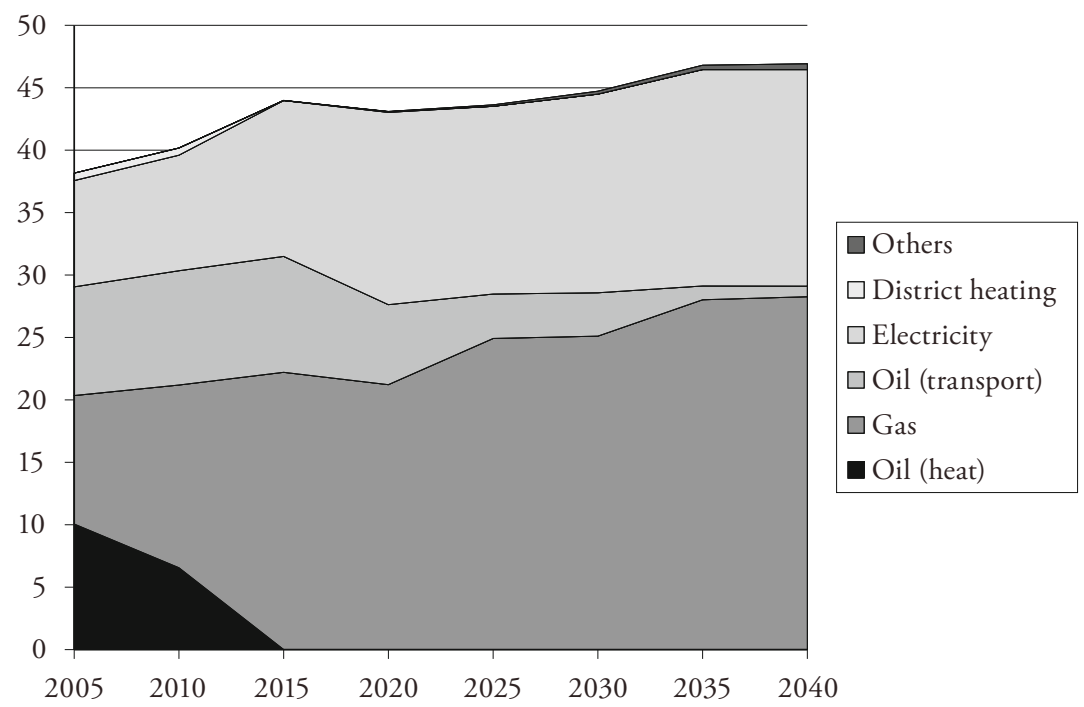

Figure 19: Energy Imports (PJ/Y) - Regulation Case.

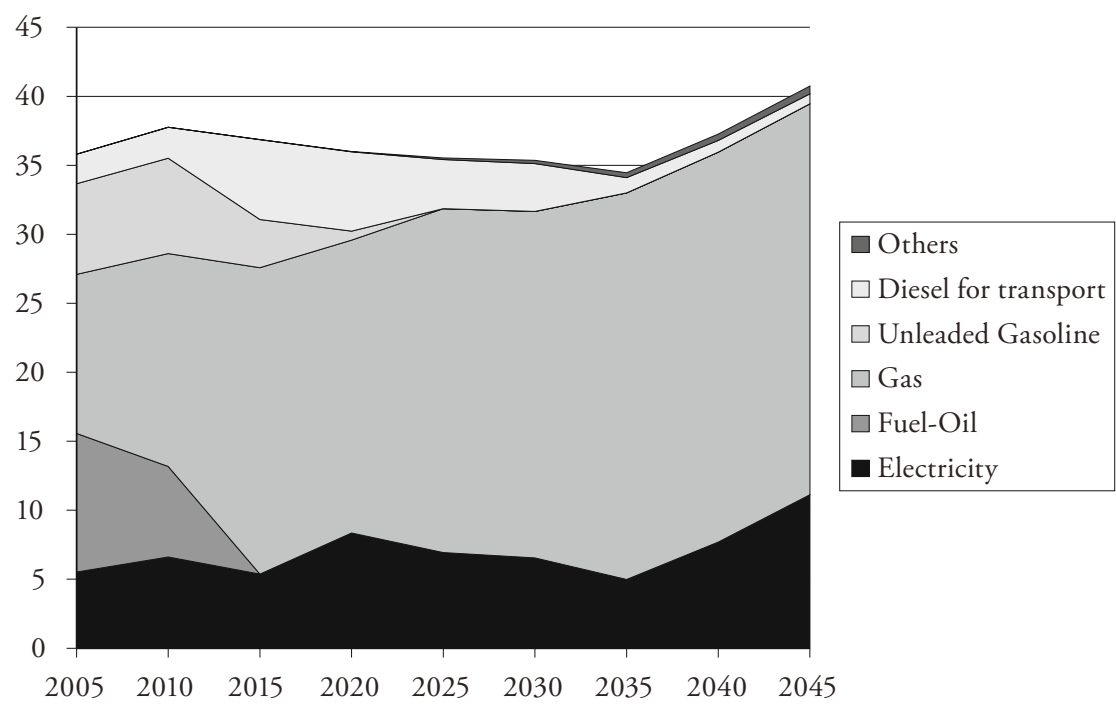


Table 13: Heat Technologies for New Buildings (MW)

\begin{tabular}{lrrrrrrrr}
\hline & 2010 & 2015 & 2020 & 2025 & 2030 & 2035 & 2040 & 2045 \\
\hline Oil furnace & 138.9 & 118 & 94 & 76 & 57 & 38 & 19 & 10 \\
Gas furnace & 42 & 71 & 87 & 136 & 188 & 209 & 304 & 378 \\
Geothermal & 0 & 100 & 100 & 100 & 100 & 100 & 100 & 100 \\
Small CHP & 0 & 66 & 66 & 66 & 66 & 304 & 304 & 310 \\
\hline
\end{tabular}

As a conclusion, imposing the constraints of limited CO2 emissions and limited electricity imports in the same time forces the penetration of local electricity production (wind, solar), efficient heating solutions (CHP) and electric mobility. With respect to the scenario with emissions constraints only, this regulation case favors the co-existence of different technologies, in particular for heat production.

\section{Stochastic Analysis}

We complement our analysis with a stochastic programming approach based on two uncertain key parameters, (i) the price of electricity imports and (ii) the penetration of electric cars, under the regulation scenario assumptions for other parameters: we consider a constraint on the emissions of $1.75 \mathrm{Mt}$ of $\mathrm{CO}_{2}$ equivalent for all periods, and the import of electricity is bounded to $15 \mathrm{PJ}$ per year.

\subsection{Uncertain Parameters and Stochastic Formulation}

We focus our stochastic analysis on the import price of electricity and the penetration of electric cars. The first parameter is particularly crucial, because the recent decisions on nuclear production taken by several countries will probably lead to an increase of the price of electricity during high demand periods. The programmed closure of the nuclear power plants in 2022 for Germany and in 2034 for Switzerland will modify the electricity imports of these countries and thus affect significantly electricity prices at the european level. To take into consideration the uncertainty related to the forthcoming electricity price, we consider a second scenario in which the electricity price in day time-slices grows twice faster from 2025 compared to the first one.

We noticed in the previous climate policies that the key technology contributing to the emission reduction is the electric car. This technology penetrates 
strongly and ultimately satisfies all or almost all the private transport needs in the Factor- 4 or Regulation scenarios. In the stochastic study, we consider two alternative scenarios. In the first one the penetration of electric vehicles is not limited whereas, in the second scenario, electric cars are limited to $25 \%$ of the market size observed in the Regulation scenario in 2045 . This constraint would represent, e.g., the exogenous effect of non-acceptability of the population due to the fact that an electric car has too low an autonomy.

Combining the uncertainty on the two parameters we end up with a stochastic event tree with four scenarios (from SC1 to SC4) that are represented in Figure 20. To generate the stochastic formulation we use the $\mathrm{DET}_{2} \mathrm{STO}^{7}$ tool (Dubois, Thénié and Vial, 2005; Thénié, van Delft, and Vial, 2007). This software automatically formulates a stochastic version of a dynamic deterministic linear program when the uncertainty is described by a simple event tree. ${ }^{8}$

Figure 20: Event Tree

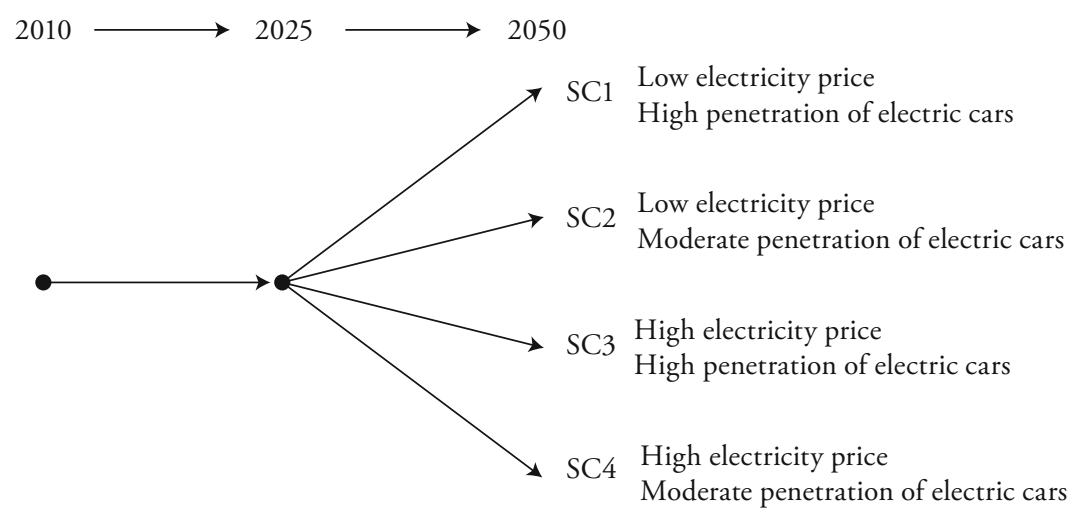

We emphasize the fact that in the stochastic programming approach the decision taken for the periods 2010-2025 will be common to all four scenarios, since there is no possibility of anticipating the realization of the events characterizing the

7 available for free on http://apps.ordecsys.com/det2sto

8 The deterministic program must be formulated in the GMPL algebraic modeling language (an open source subset of AMPL), and must comply with few conventions. DET2STO automates the formulation of this program via a set of model construction and transformation rules. 
periods 2030-2050. This is the main advantage of this approach over a simple analysis of the different scenarios. It corresponds to the actual situation of a decision maker, which could be summarized by "act and learn".

\subsection{Analysis of Stochastic Scenarios}

In 2020, the electric vehicles penetrate for all scenarios at a moderate level, which corresponds roughly to the bound imposed for the electrical vehicle fleet in scenarios 2 and 4 . In scenarios 1 and 3, electric vehicles are used very intensively after 2030. It appears that the main driver of the stochastic analysis is the availibility of electric cars, the higher price of electricity having a relatively small impact on electric car penetration (Figure 21) and electricity imports (Figure 22). In Scenario 4, the number of electric cars is restricted and one must invest in other clean technologies to satisfy the emission constraints and consume the stored electricity. Therefore we observe a penetration of electric heat and hot water technologies for houses and buildings. As expected, the constraint on emissions is active for all scenarios.

Figure 21: Activity of Electric Cars (in $1000 \mathrm{~km} \times$ Vehicle / Day).

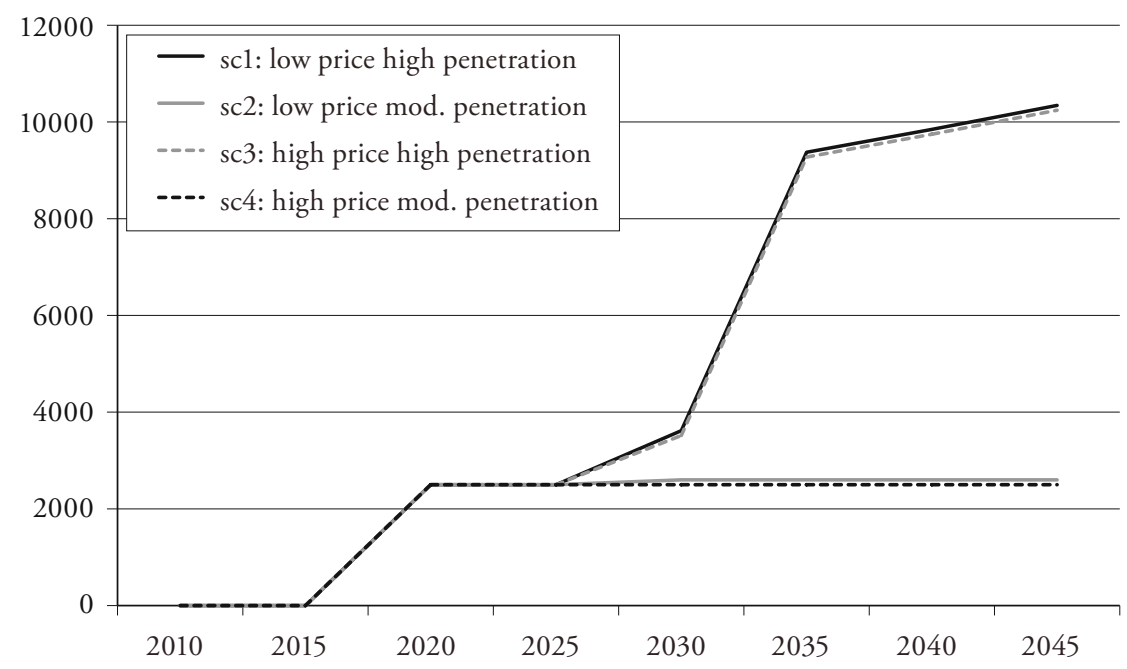


Figure 22: Electricity Imports (PJ/Y).

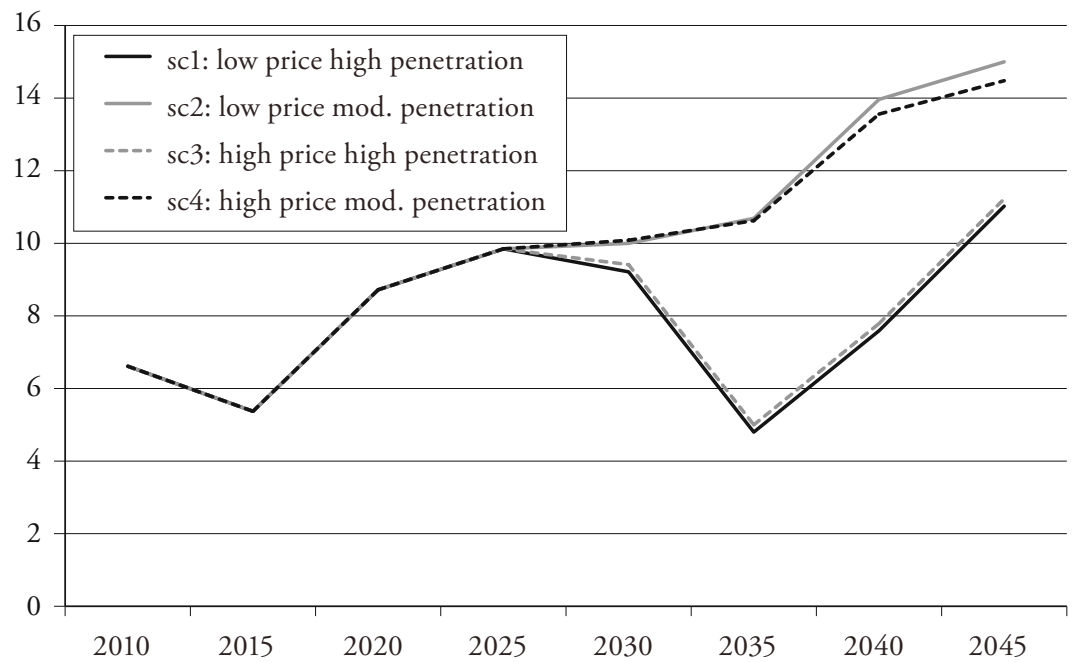

\section{Conclusion}

In this paper we have shown how to represent renewable and smart grid technologies in a techno-economic model tailored for regional analysis of energy $\&$ environment policies. The new technologies considered include electric cars with battery storage and decentralized gas fuel cell CHP units with heat storage. Renewables include wind mills and PV units that can be used to charge electric cars batteries in a smart grid environment. The smart grid allows an optimal use of the charge and discharge periods of the storage units, taking into consideration the relative implicit price of commodities at different time-slices in the load curve. These storage technologies are also available for the peak-load reserve needs. A model has been proposed, for an energy system that corresponds roughly to the Geneva canton electricity and gas grids. In these simulations it appears that these technologies may play an important role in the development of a sustainable energy system, when one limits the global amount of imported electricity as well as the quantity of $\mathrm{CO}_{2}$ emitted in the canton at the horizon 2045. A stochastic programming analysis of multiple scenarios with a possibly high price of imported electricity during high demand time-slices shows that these technologies can be used to exploit the big price difference between electricity imports during the night or during the day. 
This modeling exercise is only a first step in the direction of a comprehensive analysis of the potential penetration of renewable technologies in a distribution network in Switzerland, which should evolve toward becoming a smart-grid to permit two-way communication between distributors, producers and consumers. Further model developments are needed to integrate a geographical analysis of the capacity limit (upper bound on installed capacities) for solar, wind, and decentralized CHP technologies. In order to properly assess these renewable and smart grid technologies, a more precise representations of the load curve and of transmission and control technologies will be needed. Also the portfolio of technologies has to be enlarged with a greater variety of storage technologies, including the pumped storage facilities that are installed in Switzerland and shared by several distributors. A better description of the anticipated investment, operation and maintenance cost is also needed. A more detailed stochastic programming analysis, taking into account the possible delays in penetration of the more advanced technologies should be performed. Finally a description of the necessary investment in information and communication technologies (ICT) necessary to support a smart grid development should be added to the model.

\section{Annex 1: Investment Cost Assumptions}

In Table 14 we report the investment costs for the different space heating technologies considered in the model.

In Table 15 we report the assumed investment costs for the new space heating technologies considered in the model.

In Table 16 we report the investment costs ${ }^{9}$ for the transport technologies considered in the model.

In Table 17 we report the investment costs for the conversion technologies considered in the model. This is complemented by Table 18 where we report our assumptions for investment cost in some smart-grid related technologies.

$91 \mathrm{Mfr}$ per $1000 \mathrm{~km} \times$ vehicle / day, correponds roughly to $33,000 \mathrm{fr}$ per vehicle, assuming a daily travel of $33 \mathrm{~km}$ per vehicle. 


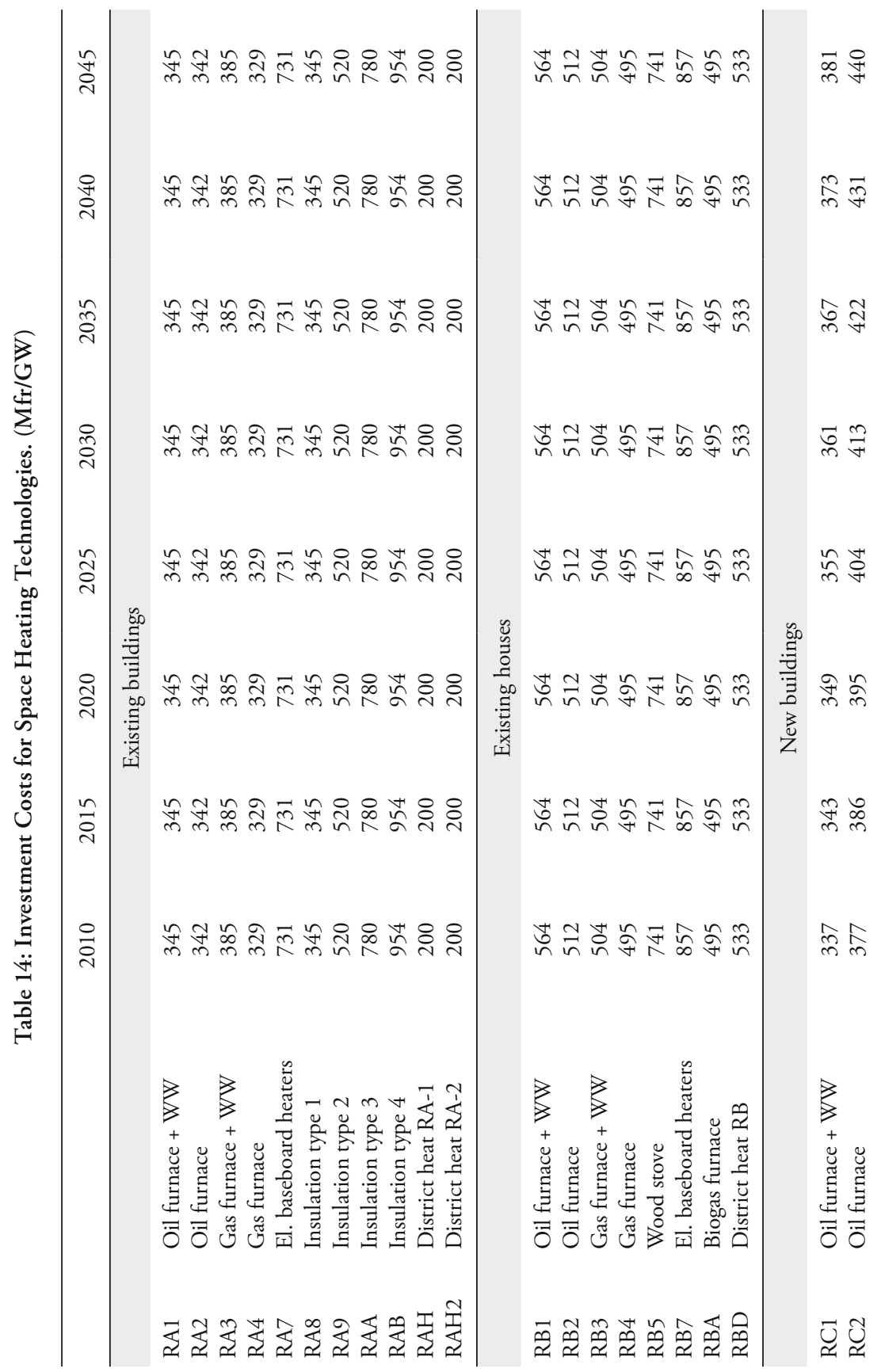

Swiss Journal of Economics and Statistics, 2012, Vol. 148 (2) 


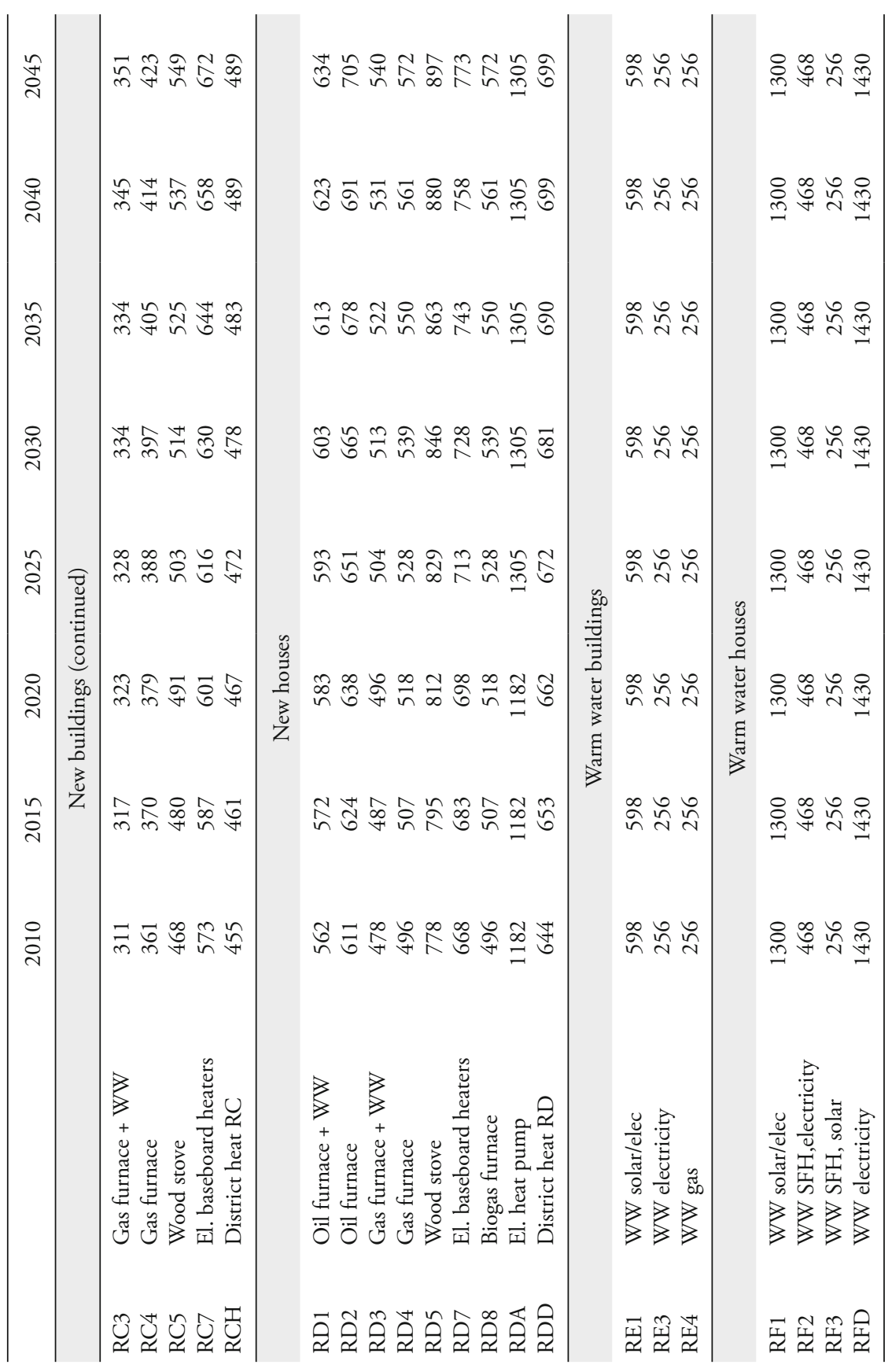




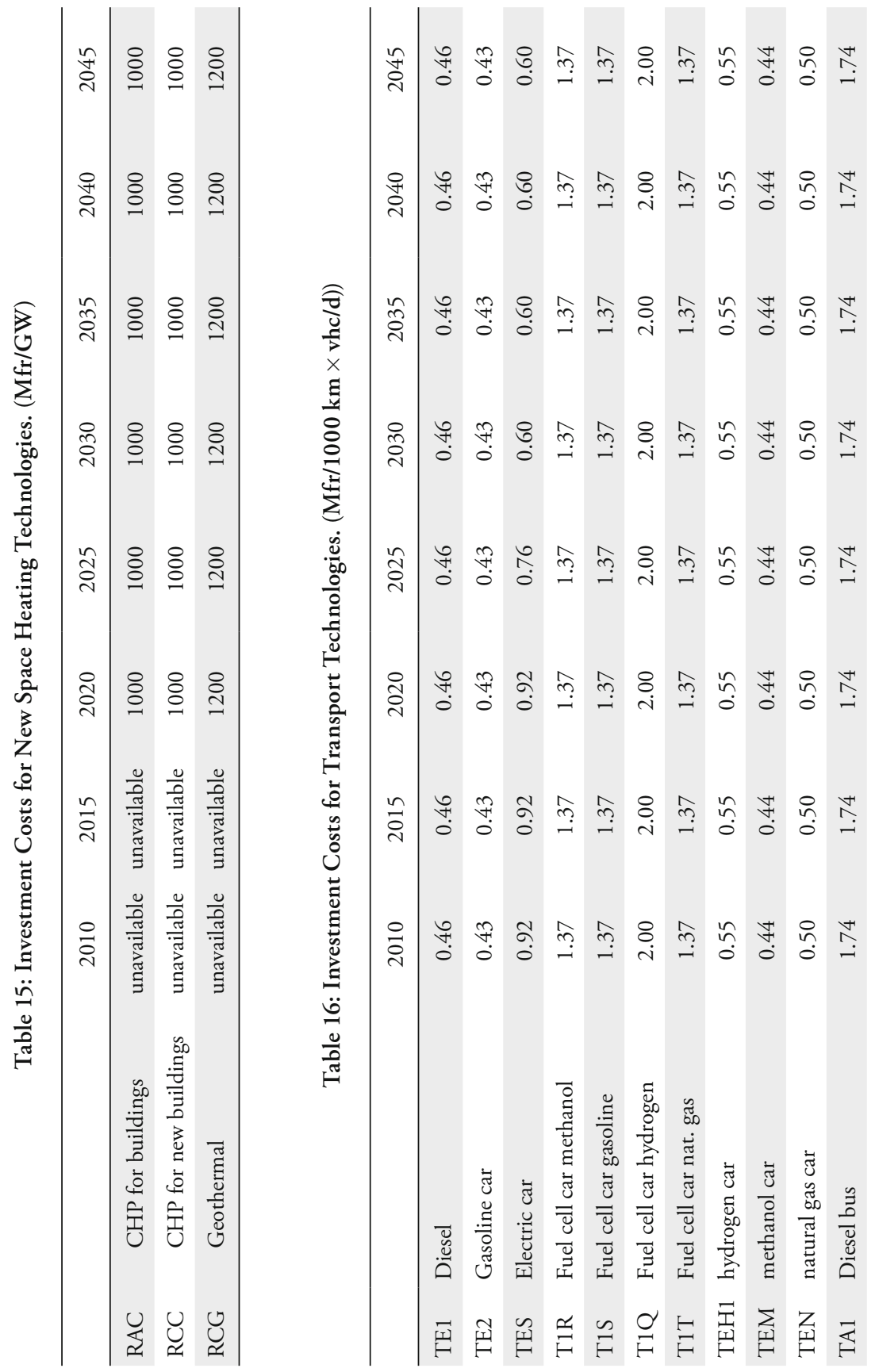




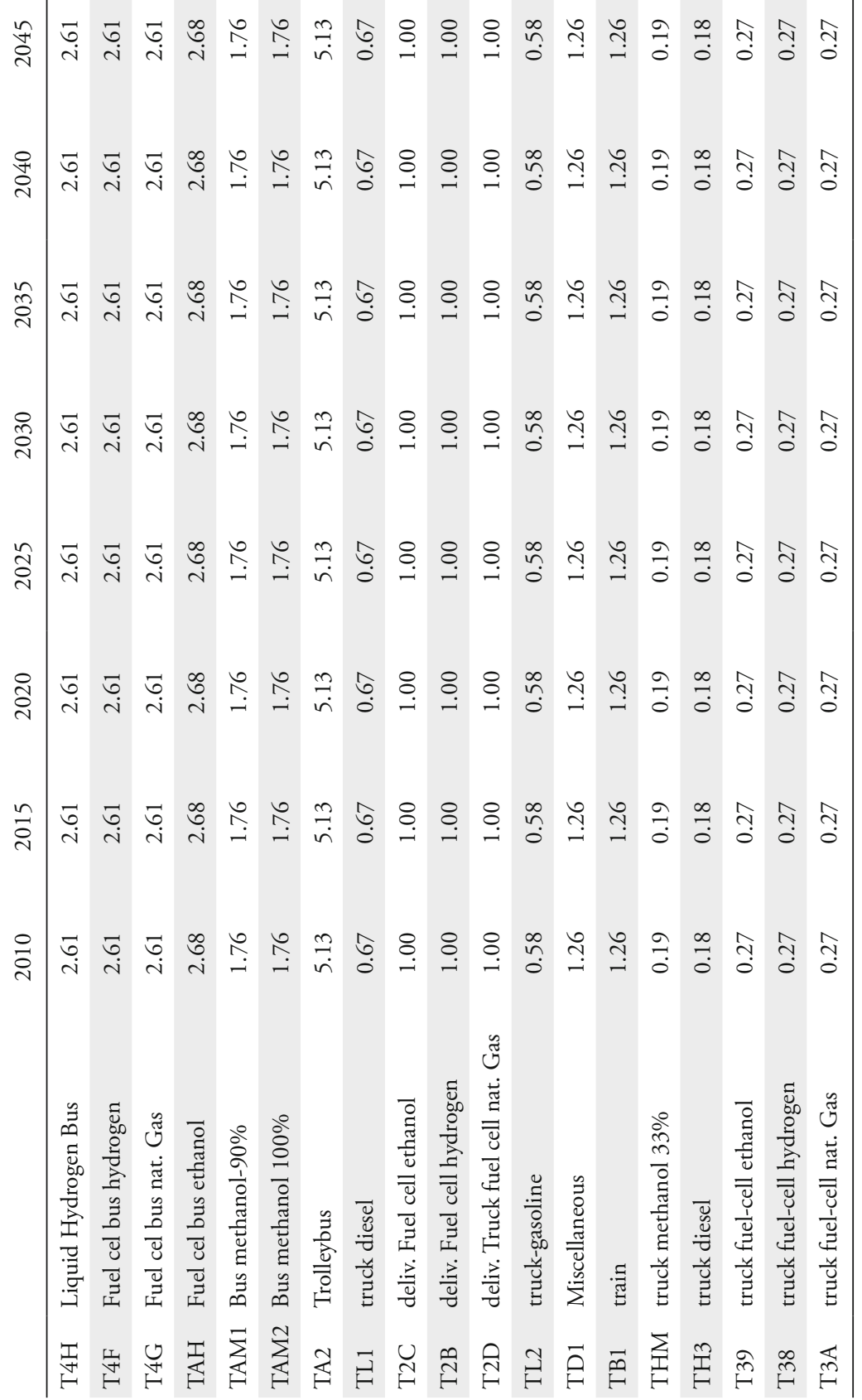




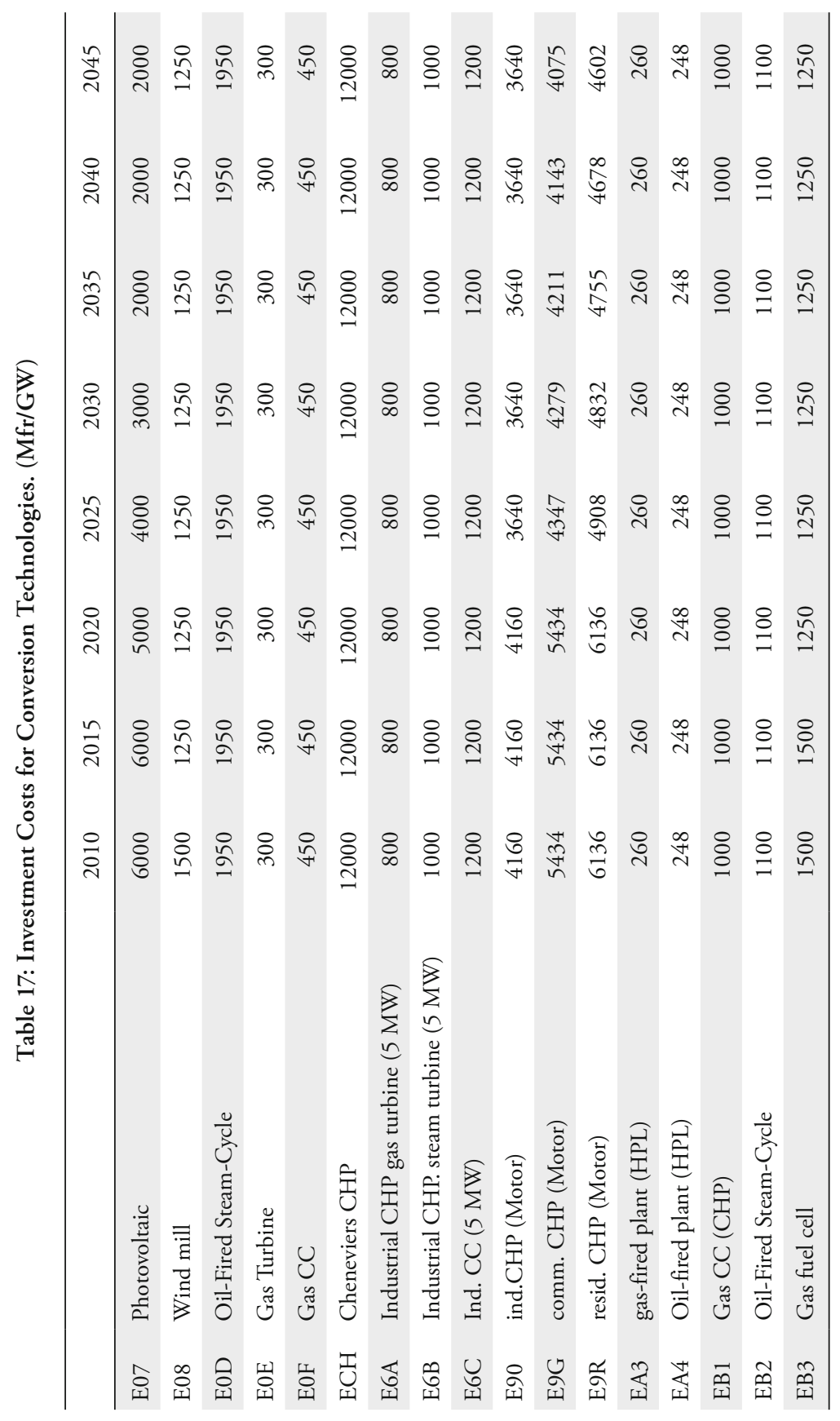




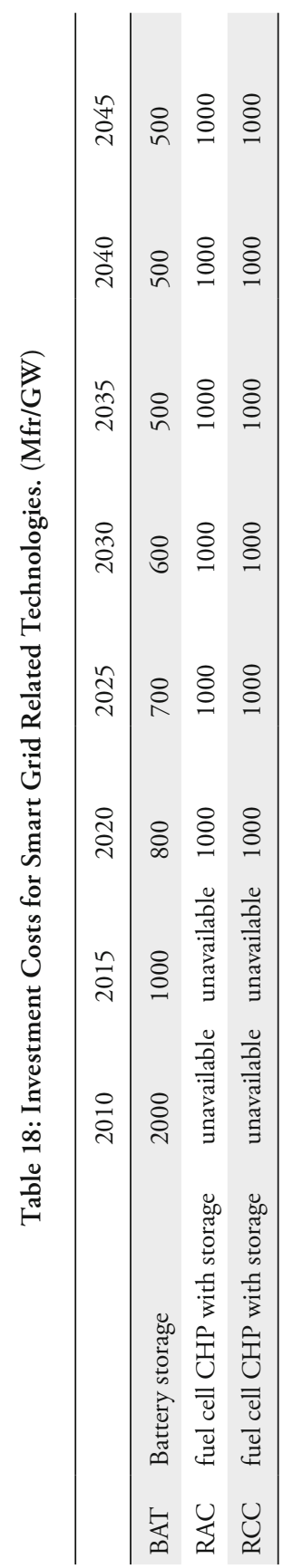




\section{Annex 2: Main Equations of the Model}

We give here a description in the modeling language code of the most important equations of ETEM.

The objective function is the function that is minimized. It represents the total discounted cost of the energy system over the horizon. It is the sum of the total discounted investment cost, the total discounted fixed cost and the total discounted variable cost minus the total discounted salvage value.

minimize OBJECTIVE :

VAR_OBJINV + VAR_OBJFIX + VAR_OBJVAR - VAR_OBJSAL;

The EQ_OBJINV equation computes the total discounted investment cost. Technologies investment costs are directly linked to the new capacity of the period. There is no delay between the time when the decision is taken and the time when the technology is installed. The technology life duration must be equal or longer than the duration of the installation period.

subject to EQ_OBJINV :

VAR_OBJINV $=$ sum $\{t$ in $T, 1$ in $L, p$ in P_MAP $[1]\}$ cost_icap $[\mathrm{t}, \mathrm{p}]^{*}$ VAR_ICAP $[\mathrm{t}, \mathrm{l}, \mathrm{p}] /\left((1+\text { discount_rate })^{* *}\left(\mathrm{nb} \_\right.\right.$completed_years $\left.\left.[\mathrm{t}]\right)\right)$;

The EQ_OBJFIX equation computes the total discounted fixed cost. Fixed costs are linked to the total installed capacities of processes.

subject to EQ_OBJFIX :

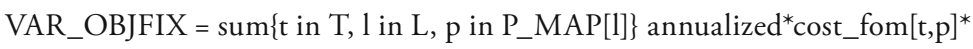

$(\operatorname{sum}\{\mathrm{t} 1$ in $1 . . \mathrm{t}: \mathrm{t} 1>=\mathrm{t}-\mathrm{life}[\mathrm{p}]+1$ and $\mathrm{t} 1>=$ avail[p]\}

VAR_ICAP $[\mathrm{t} 1, \mathrm{l}, \mathrm{p}]+$ fixed_cap $[\mathrm{t}, \mathrm{l}, \mathrm{p}])$ \# capacity[t,p]

$/\left((1+\text { discount_rate })^{* *}\left(n b \_c o m p l e t e d \_y e a r s[t]\right)\right)$;

The EQ_OBJVAR equation computes the total discounted variable cost. Variable costs are linked to the activities of processes and to the importation and exportation of commodities.

subject to EQ_OBJVAR :

VAR_OBJVAR $=\operatorname{sum}\{t$ in $T\}$ annualized ${ }^{*}$ 


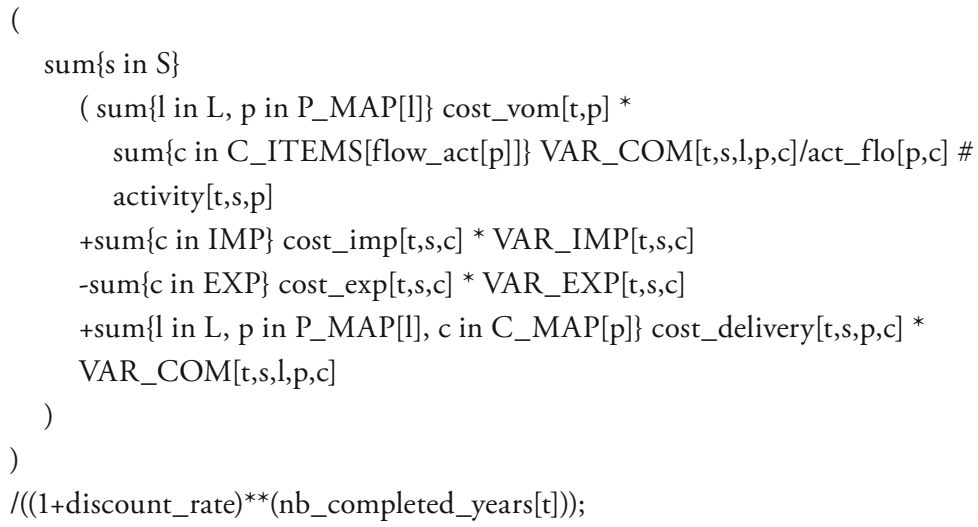

The EQ_OBJSAL equation computes the total discounted salvage value that represents the value that should be assigned to the processes still available at the end of the planning horizon (e.g. when their technical lives exceed the model's horizon). By omitting this value, too many investments would occur near to the termination of time horizon (end-of-period effect).

subject to EQ_OBJSAL :

VAR_OBJSAL $=\operatorname{sum}\{t$ in $T, 1$ in $L, p$ in P_MAP[l] : $t>=$ avail[p] and

t+life[p]>nb_periods +1$\}$

$$
\text { salvage[t,p]*cost_icap[t,p]*VAR_ICAP }[\mathrm{t}, \mathrm{l}, \mathrm{p}] /
$$

$\left((1+\text { discount_rate })^{* *}(\right.$ nb_completed_years $\left.[\mathrm{t}])\right)$;

The EQ_COMBAL equation defines the balance equation of a commodity. It ensures that, at any time-slices, the supply of the commodity (by importation or production) is equal or greater than the delivery of the commodity (exportation, consumption or demand).

subject to EQ_COMBAL $\{t$ in $T$, $s$ in $S$, c in $C\}$ :

$\left(\operatorname{sum}\left\{1\right.\right.$ in $L, p$ in $P_{-} P R O D[c]$ inter P_MAP $\left.[1]\right\}$ VAR_COM[t,s,l,p,c] +

if $\mathrm{c}$ in IMP then

$$
\text { VAR_IMP }[t, s, c]
$$

else

0

)$^{*}$ network_efficiency[c]

$>=$

if $\mathrm{c}$ not in DEM then 
$\operatorname{sum}\{1$ in L, p in P_CONS[c] inter P_MAP[1] $\}$ VAR_COM[t,s,l,p,c] + if $c$ in EXP

$$
\text { then VAR_EXP[t,s,c] }
$$

else

0

else

frac_dem $[s, c]^{*}$ demand $[t, c]$;

The EQ_CAPACT equation defines the relation between activity and total installed capacity of a process and ensures that the activity is less than the theoretic upper bound on activity defined by the capacity installed.

subject to EQ_CAPACT $\{t$ in $T$, $s$ in $S, 1$ in L, p in P_MAP $[1]\}$ :

$\operatorname{sum}\{c$ in C_ITEMS[flow_act[p]]\} VAR_COM[t,s,l,p,c]/act_flo[p,c] \# activity[t,s,p]

$<=$ avail_factor[t,s,p] $]^{*}$ cap_act $[\mathrm{p}]^{*}$ fraction $[\mathrm{s}]^{*}$

$(\operatorname{sum}\{\mathrm{t} 1$ in $1 . . \mathrm{t}: \mathrm{t} 1>=\mathrm{t}-\mathrm{life}[\mathrm{p}]+1$ and $\mathrm{t} 1>=$ avail[p]\}VAR_ICAP[t1,l,p]+fixed_cap[t,l,p]);

\# capacity[t,p]

The EQ_PTRANS equation defines a relation between an input flow and an output flow of a process, taking into account the efficiency of the energy transformation through the process.

subject to EQ_PTRANS $\{\mathrm{t}$ in T, $s$ in $\mathrm{S}, 1$ in L, p in P_MAP[1], cg_in in FLOW_IN[p], cg_out in FLOW_OUT[p]:

eff_flo[cg_in,cg_out] $>0\}$ :

$\operatorname{sum}\left\{c \_o\right.$ in C_ITEMS[cg_out] $\}$ VAR_COM[t,s,l,p,c_o]

$=$

eff_flo[cg_in,cg_out] ${ }^{*} \operatorname{sum}\left\{c \_i\right.$ in C_ITEMS[cg_in] $\}$ VAR_COM[t,s,l,p,c_i];

The EQ_PEAK equation defines the balance equation of a commodity at peak time. It ensures that the installed capacity is enough to meet the highest demand in any time-slice, taking into account a reserve margin and adjustments in the average production.

subject to EQ_PEAK $\{\mathrm{t}$ in $\mathrm{T}, \mathrm{s}$ in $\mathrm{S}, \mathrm{c}$ in $\mathrm{C}\}$ :

$1 /(1+$ peak_reserve $[t, s, c]) *($

$\operatorname{sum}\{1$ in L, p in P_PROD[c] inter P_MAP[l] : c in C_ITEMS[flow_act[p]]\}

cap_act[p]*act_flo[p,c]*peak_prod[p,s,c]*fraction $[s]^{*}$

$(\operatorname{sum}\{\mathrm{t} 1$ in $1 . . \mathrm{t}: \mathrm{t} 1>=\mathrm{t}-\mathrm{life}[\mathrm{p}]+1$ and $\mathrm{t} 1>=$ avail[p] $\}$ VAR_ICAP[t $1,1, \mathrm{p}]+$ fixed_cap$[\mathrm{t}, 1, \mathrm{p}])$ 


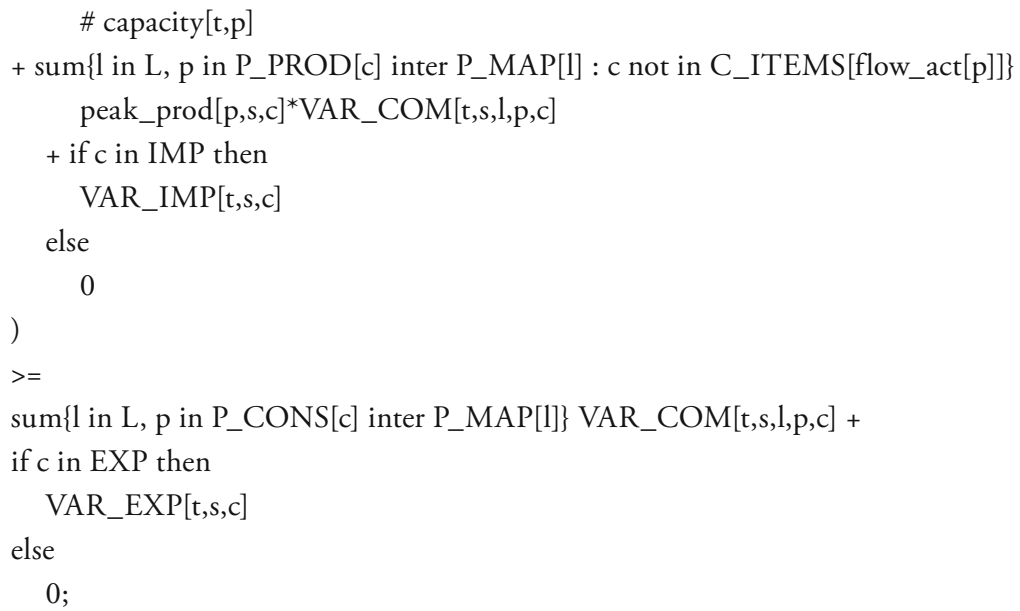

The Capacity transfer equations describe the relationship between the life of technologies, investments made, capacities available prior to the planning period and finally capacities installed. These constraints provide the dynamical structure to the model. They represent the way installed capacities result from past investments. One has also to take into account what residual capacity still remains available.

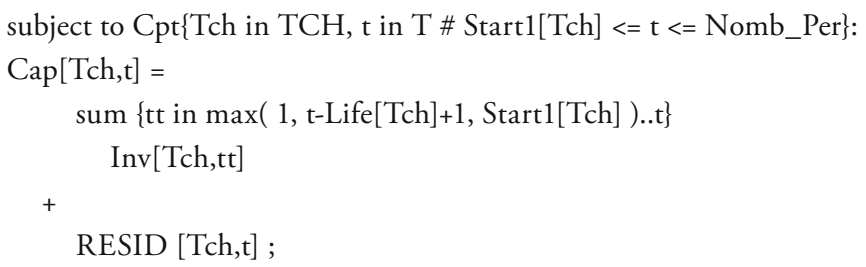

\section{References}

Acha, S., T. Green, and N. Shah (2010a), "Effects of Optimised Plug-In Hybrid Vehicle Charging Strategies on Electric Distribution Network Losses", in IEEE PES Transmission and Distribution Conference and Exposition, New Orleans, USA.

Acha, S., T. Green, and N. Shah (2010b), "Techno-Economical Tradeoffs from Embedded Technologies with Storage Capabilities on Electric and Gas 
Distribution Networks", in IEEE Power and Energy Society General Meeting, Minneapolis, MN, USA.

Berger, C., R. Dubois, A. Haurie, E. Lessard, and R. Loulou (1990), "Assessing the Dividends of Power Exchange between Québec and New York State: A Systems Analysis Approach", International Journal of Energy Research, 14, pp. 253-273.

Brown, James E., Chris N. Hendry, and Paul Harborne (2007), "An Emerging Market in Fuel Cells? Residential Combined Heat and Power in four Countries", Energy Policy, 35(4), pp. 2173-2186, URL http://dx.doi. org/10.1016/j.enpol.2006.07.002.

Caratti, P., A. Haurie, D. Pinelli, and D. S. Zachary (2003), "Exploring the Fuel Cell Car Future: An Integrated Energy Model at the City Level", in Urban Transport IX, Proceedings Urban Transport 2003, Ninth International Conference on Urban Transport and the Environment in the 21st Century, 10-12 March 2003 Crete, Greece, L. J. Sucharov and C. A. Brebbia, eds., Southampton: WIT Press.

Carlson, D., A. Haurie, J.-P. Vial, and D. S. Zachary (2004), "Large Scale Convex Optimization Methods for Air Quality Policy", Automatica, pp. 385-395.

Drouet, L. and J. Thénié (2009), "An Energy-Technology-Environment Model to Assess Urban Sustainable Development Policies - Reference Manual v.2.1", Tech. rep., Ordecsys.

Dubois, A., J. Thénié, and J.-Ph. Vial (2005), “Stochastic Programming: The det2sto Tool”, Tech. rep., Logilab, HEC, University of Geneva and Ordecsys, URL http://www.ordecsys.com/det2sto.

Fourer, R., D. M. Gay, and B. W. Kernighan (1993), AMPL: A Modeling Language for Mathematical Programming, Duxbury Press, Brooks, Cole Publishing Company.

Fragnière, E. (1995), Choix énergétiques et environnementaux pour le canton de Genève, Thesis no 412, Faculté des Sciences Economiques et Sociales, Université de Genève, Genève.

Galus, M. D. and G. Andersson (2008), "Demand Management of Grid Connected Plug-In Hybrid Electric Vehicles (PHEV)", in IEEE Energy 2030 Conference.

Haw kes, A.D. and M.A. Leach (2007), "Cost-Effective Operating Strategy for Residential Micro-Combined Heat and Power”, Energy, 32(5), pp. 711-723, URL http://dx.doi.org/10.1016/j.energy.2006.06.001.

HiLl, D. (1996), The Baked Apple? Metropolitan New York in the Greenhouse, vol. 790, Annals of The New York Academy of Sciences. 
Hirschberg, S., A. Wokaun, and C. Bauer (2005), "Outlook for CO2-Free Electricity in Switzerland, New Renewable Energy Sources”, Energie Spiegel 14, PSI Paul Scherrer Institute.

Howells, M., H. Rogner, N. Strachan, C. Heaps, H. Huntington, S. Kypreos, A. Hughes, S. Silveira, J. DeCarolis, M. Bazillian, and A. Roenrl (2011), "Osemosys: The Open Source Energy Modeling System: An Introduction to Its Ethos, Structure and Development", Energy Policy.

Huang, Xinhong, Zhinao Zhang, and Jin Jiang (2006), "Fuel Cell Technology for Distributed Generation: An Overview", in Industrial Electronics, 2006 IEEE International Symposium on, vol. 2, pp. 1613-1618, URL http:// dx.doi.org/10.1109/ISIE.2006.295713.

IEA (2011a), "Energy Prices and Taxes, Second Quarter, 2011”, IEA Energy Papers, OECD, International Energy Agency.

IEA (2011b), "World Energy Outlook", IEA Energy Papers, OECD, International Energy Agency.

Kempton, Willett, and Jasna Tomic (2005), "Vehicle-to-Grid Power Fundamentals: Calculating Capacity and Net Revenue", Journal of Power Sources, 144(1), pp. 268-279, URL http://dx.doi.org/10.1016/j.jpowsour.2004.12.025.

Loulou, R., A. Kanudia, and D. Lavigne (1996), "GHG Abatement in Central Canada with Inter-Provincial Cooperation”, Energy Studies Review, 8(2), pp. 120-129.

Marnay, C., G. Venkataramanan, M. Stadler, A. Siddiqui, R. Firestone, and B. Chandran (2008), "Optimal Technology Selection and Operation of Commercial-Building Microgrids", IEEE Transactions on Power Systems, 23(3), pp. 975-982.

Neef, H.-J. (2009), "International Overview of Hydrogen and Fuel Cell Research", Energy, 34(3), pp.327-333, URL http://dx.doi.org/10.1016/j. energy.2008.08.014, <ce:title>WESC 2006</ce:title><xocs:full-name>6th World Energy System Conference</xocs:full-name $><$ ce:title $>$ Advances in Energy Studies</ce:title > <xocs:full-name $>5$ th workshop on Advances, Innovation and Visions in Energy and Energy-related Environmental and SocioEconomic Issues</xocs:full-name>.

OFSTAT-GE (2005-2010), «Annuaire statistique du canton de Genève».

Shin-ICHI, I. (2010), "Modelling Load Shifting Using Electric Vehicles in a Smart Grid Environment", IEA Energy Papers 7, OECD, International Energy Agency.

Streckiene, G., V. Martinaitis, A. N. Andersen, and J. Katz (2009), "Feasibility of CHP-Plants with Thermal Stores in the German Spot Market", Applied Energy, 86(11), pp. 2308-2316. 
Sundberg, J., P. Gipperth, and C.-O. Wene (1994), "A Systems Approach to Municipal Solid Waste Management: A Pilot Study of Göteborg”, Waste Management and Research, 12(1), p. 73.

Thénié, J., Ch. van Delft, and J.-Ph. Vial (2007), "Automatic Formulation of Stochastic Programs via an Algebraic Modeling Language”, Computational Management Science, 4, pp. 17-40.

Weidmann, N., R. Kannan, and H. Turton (2012), "Swiss Climate Change and Nuclear Policy: A Comparative Analysis Using an Energy System Approach and a Sectoral Electricity Model", This issue.

Wene, C.-O. and B. Rydén (1988), "A Comprehensive Energy Model in the Municipal Energy Planning Process", European Journal of Operational Research, 33(2), pp. 212-222.

Zachary, D. S., L. Drouet, U-Leopold, and L. Aleluia Reis (2011), "TradeOffs between Energy Cost and Health Impact in a Regional Coupled EnergyAir Quality Model: The LEAQ model”, Environmental Research Letters, 6.

\section{SUMMARY}

In this paper we present the regional techno-economic model ETEM, designed for the analysis of regional energy/environment systems and we show how it can be used to explore the possible penetration of new technologies in a region corresponding roughly to the canton of Geneva. We investigate three scenarios with different constraints on $\mathrm{CO}_{2}$ emissions and electricity imports and show the essential role played by new technologies, linked through a smart grid, in the effort toward a sustainable energy system. We strengthen our conclusion with a stochastic approach dealing with uncertainty in future electricity prices and electric car technology penetration. 